\title{
Genetic Variation, Heritability, Phenotypic and Genotypic Correlation Studies for Yield and Yield Components in Promising Barley Genotypes
}

\author{
Jalal A. Al-Tabbal (Corresponding author) \\ Department of Applied Science, Al-Huson University College \\ Al-Balqa`Applied University, Al-Huson, Jordan \\ Tel: 962-79-766-0137_E-mail: Jaltabbal@bau.edu.jo \\ Ahmad H. Al-Fraihat \\ Department of Applied Science, Ajloun University College \\ Al-Balqa`Applied University, Ajloun, Jordan
}

Received: August 16, 2011

Accepted: August 30, 2011

Online Published: December 29, 2011

doi:10.5539/jas.v4n3p193

URL: http://dx.doi.org/10.5539/jas.v4n3p193

\begin{abstract}
Eighty six promising new barley genotypes and three checks including one indigenous cultivar (Hordeum vulgare L. var Rum) were grown in two successive seasons of 2005 and 2006 to assess the presence of variability for desired traits and amount of variation for different parameters. Genetic parameters, correlations, and partial regressions were estimated for all the traits. Analysis of variance revealed significant differences among entries for all the characters. The estimates of genotypic coefficient of variation (GCV) and phenotypic coefficient of variation (PCV) were high for grain yield per plant, biological yield and number of kernels per main spike. Broad sense heritability estimates for various traits ranged from 68 to $99.7 \%$. Grain yield per plant showed high significant positive genetic and phenotypic correlation with only number of kernels per main spike. Multiple correlations of characters (0.36), via. fertile tiller number and number of kernels per main spike which were significant with grain yield were far from the multiple correlation of all characters (0.96). The total variability calculated through multiple correlation in the population for yield improvement accounted by fertile tiller number and number of kernels per main spike was $36 \%$ compared to $96 \%$ accounted by all other characters. It was concluded that more fertile tiller number and number of kernels per main spike are major yield contributing factors in selecting high yielding barley cultivars.
\end{abstract}

Keywords: Phenotypic, Genotypic, Coefficient, Variation, Genetic advance, Heritability, Barley

\section{Introduction}

Barley is a fourth most important cereal crop after wheat, rice and maize, cultivated successfully in a wide range of climate. This crop has potentials for growing under drought and saline conditions. Barley grain is used as feed, food, while barley straw provides an important source of roughage. In Jordan, barley is the predominant crop in areas of below $300 \mathrm{~mm}$ of annual rainfall, which are characterized by high interseasonal and intraseasonal variation in terms of amount and distribution of rainfall. In these areas barley is mainly grown as animal feed and both the grain and the straw are utilized (Al-Jamali et al. 2002; Tawaha and Turk 2002; Turk et al. 2003). The world production of barley decreased by 3.5\% during the period 1995-1998 to 2005-2008, while in Jordan, barley production decreased by $57 \%$ (FAO, 2009). The low productivity of barley in Jordan is due to wide seasonal variability, low amount of rainfall, poor soil moisture conservation, poor stand resulting from lack of weed control, and low yield potential genotypes (Tawaha et al. 2001, 2002, 2003; Turk and Tawaha 2003; Al-Jamali et al. 2002; Tawaha and Turk 2002; Turk et al. 2003).

Different methods could be used to increase cereal production, such as increasing area of production, effective cultural practices, and using improved cultivars (Cassman 1999). In Jordan, as land is limited and most of the production area is under semi-arid conditions, developing high-yielding cultivars adapted to local conditions could 
be employed, understanding the magnitude of existing variability, proper characterization of the most important physiological traits and their interrelationships with yield and yield components would be extremely helpful in the synthesis of most efficient and highly productive genotypes (Joshi et al. 1982). So, cereal improvement depends on the continuous supply of new germplasm as donors of various genes of agronomic importance. The development of high yielding-cultivars is the main objective of any breeding programs in the world (Ehdaie and Waines, 1989). One of the main objectives of any breeding program is to produce high-yielding and better-quality lines for release as cultivars to farmers. The prerequisite to achieve this goal is to find sufficient amount of variability, in which desired lines are to be selected for further manipulation to achieve the target. Introduction of new populations can be made from one region to the other easily and may be used for further manipulation to develop new breeding lines (Ifftikhar et al., 2009). Identification of better genotypes with desirable traits and their subsequent use in breeding program and establishment of suitable selection criteria can be helpful for successful varietals improvement program. Analysis of variability among the traits and the association of a particular character in relation to other traits contributing to yield of a crop would be of great importance in planning a successful breeding program (Mary and Gopalan 2006). Development of high-yielding cultivars requires a thorough knowledge of the existing genetic variation for yield and its components. The observed variability is a combined estimate of genetic and environmental causes, of which only the former one is heritable. However, estimates of heritability alone do not provide an idea about the expected gain in the next generation, but have to be considered in conjunction with estimates of genetic advance, the change in mean value among successive generations (Shukla et al., 2006). A survey of genetic variability with the help of suitable parameters such as genetic coefficient of variation, heritability estimates and genetic advance are absolutely necessary to start an efficient breeding program (Atta et al., 2008). Assessment of the extent of genetic variability within barley, is fundamental for barley breeding programs and the conservation of genetic resources, and is particularly useful as a general guide in the choice of parents for breeding hybrids. The objectives of the present study were to assess and evaluate genetic variability of barley germplasm based on agro-morphological traits.

\section{Materials and Methods}

\subsection{Plant Materials}

Eighty six promising new barley genotypes from the International Center for Agricultural Research in the Dry Areas (ICARDA) were used. Harmal (the improved 2-rowed check variety), Matnan-01(the improved 6-rowed check variety), and Rum (the improved 6-rowed local check variety) were the checks. Entry name and pedigree are presented in Table 1.

\subsection{Field Experimental Setup}

Genotypes were sown in the first week of December 2005 and the second week of December 2006 in Al-huson Field Campus in a randomized complete block design with three replications. The experimental plots consisted of 6 rows of $2.5 \mathrm{~m}$ length with $30 \mathrm{~cm}$ spaces and they were sown by hand. The plant density of 300 plants per $\mathrm{m}^{2}$ and recommended dose of fertilizer (100:70:50, NPK) $\mathrm{kg}$ per ha were applied. Weeds were removed by hand prior to flowering stage. Standard cultural practices were followed for raising the crop.

\subsection{Weather Conditions}

The precipitation and average temperature for the 2005/2006 and 2006/2007 cropping seasons in Al-huson Field Campus are presented in Table 2. Total precipitation in 2005/ 2006 was $261.8 \mathrm{~mm}$, while it was $276.8 \mathrm{~mm}$ in 2006/2007.

\subsection{Characters Studied}

The characters measured included biological yield pert plant (g) (BY), grain yield per plant (g) (GY), plant height $(\mathrm{cm})(\mathrm{PH})($ measured from the base of the plant to the tip of the plant at the time of physiological maturity), tillers per pant (TN) (recorded by counting the number of tillers per plant selected at random), number of fertile tillers (FTN), number of kernels per main spike (KN), thousand kernel weight of main spike (g) (TKW), number of days to heading (HD) (counted from the date of sowing to the date on which approximately $50 \%$ tillers produced spikes.), number of days to maturity (MD) (calculated when the plants were physiologically mature (the stage when color of plant changes from green to golden yellow and its tillers can break easily with hands)), and grain filling period (GFP). From these measurements, estimates of harvest index using Eq. 1 were also computed and analyzed.

$$
H I=G Y / B Y
$$




\subsection{Genetic Parameters Estimates}

Heritability in broad sense $\left(\mathrm{H}^{2}\right.$ or $\mathrm{h}^{2)}$ was estimated according to Falconer (1989) using eq. 2:

$$
h 2=\frac{\sigma 2 \mathrm{~g}}{\sigma 2 \mathrm{ph}}
$$

$h^{2}$ : Heritability; $\sigma_{\mathrm{g}}^{2}$ : genotypic variance and $\sigma_{\mathrm{ph}}^{2}$ : phenotypic variance. Genotypic $\left(\sigma_{\mathrm{g}}^{2}\right)$ and Phenotypic variances $\left(\sigma_{\mathrm{ph}}^{2}\right)$ were obtained from the analysis of variance table according to Comstock and Robinson (1952) using eq. 3 and eq. 4 :

$$
\begin{aligned}
& \sigma 2 \mathrm{~g}=\frac{\mathrm{MS} 1-\mathrm{MS} 2}{\mathrm{r} \times \mathrm{s}} \\
& \sigma 2 \mathrm{ph}=\frac{\mathrm{MS} 1}{\mathrm{r} \times \mathrm{s}}
\end{aligned}
$$

(Where r: replication, s: season MS1: Mean square for cultivar, MS2: Mean square for cultivar $\times$ season).

The mean values were used for genetic analyses to determine Phenotypic Coefficient of Variation (PCV) and Genotypic Coefficient of Variation (GCV), according to Singh and Chaudhury (1985) using eq. 5 and eq. 6:

$$
\begin{aligned}
& \operatorname{GCV}(\%)=\frac{\sqrt{\sigma 2 \mathrm{~g}}}{\mathrm{x}} * 100 \\
& \operatorname{PCV}(\%)=\frac{\sqrt{\sigma 2 \mathrm{ph}}}{\mathrm{x}} * 100
\end{aligned}
$$

Where:

$\sigma 2 \mathrm{~g}=$ genotypic variance.

$\sigma 2 \mathrm{ph}=$ phenotypic variance.

$X=$ sample mean.

Genetic advance (GA) was calculated with the method suggested by Allard (1960); Singh and Chaudhury (1985) using eq. 7 :

$$
G A=k . \sigma p h . h 2
$$

Where

GA: genetic advance.

$\mathrm{K}$ : constant $=2.06$ at $5 \%$ selection intensity.

$\sigma p h:$ square root of phenotypic variance .

$h 2$ : Heritability.

$$
\mathrm{GA} \text { as } \% \text { of mean }(\mathrm{GAM})=(\mathrm{GA} / \text { mean value }) * 100
$$

Phenotypic and genotypic correlations were estimated using the standard procedure suggested by Miller et al. (1958) and Kashiani and Saleh (2010) from the corresponding variance and covariance components using eq. 9 and eq. 10:

Phenotypic correlation coefficient

Genotypic correlation coefficient

$$
r p x y=\frac{\sigma p x y}{\sqrt{\sigma 2 \mathrm{px} * \sigma 2 \mathrm{py}}}
$$

$$
r g x y=\frac{\sigma g x y}{\sqrt{\sigma 2 g x * \sigma 2 g y}}
$$

Where, $\boldsymbol{r}$ pxy $=$ phenotypic correlation coefficient between characters $\mathrm{X}$ and $\mathrm{Y}$ and $\boldsymbol{r} g x y=$ Genotypic correlation coefficients between characters $\mathrm{X}$ and $\mathrm{Y}$. 


\subsection{Statistical Analysis}

Analysis of variance, using randomized complete block design, was computed for all the characters evaluated using the computer software system of SAS (SAS Institute, 2002).

\section{Results}

\subsection{Phenotypic Variation}

The results from analyses of variance over two years for the investigated characteristics are presented in Table 3 . Grain yield and some grain quality characteristics of the eighty six promising new barley genotypes and the three check cultivars which were introduced from ICARDA were assessed in a two year study and a high significant variability among the promising barley genotypes were determined with respect to the studied parameters (Table 4). Effects of cultivar $(\mathrm{V})$ and year $(\mathrm{Y})$ were found to be significant for all the parameters, except for the effect of year of grain yield per plant, biological yield per plant, harvest index per plant, and thousand kernel weight. However, the interaction of $\mathrm{Y} \times \mathrm{V}$ was not significant. The mean values of the characteristics studied are shown in Table 5 .

\subsection{Promising Barley Genotypes VS Standard Cultivars}

Comparisons between the promising barley genotypes and the improved cultivars revealed that, in general, promising barley genotypes were similar to the check cultivars except for kernel number and heading date. Local check cultivar (Rum) has greater number of kernels than the promising barley genotypes. Also, Matnan check was later in heading than other promising barley genotypes. The mean values of other characters compared to the check cultivars are presented in Table 5. There was one promising barley genotype (Entry no. 76) that was superior to the local check Rum for grain yield per plant. The grain yield and other characters of the superior plant and check cultivars are presented in Table 6. Among yield components, this genotype (Entry no. 76) was better than the check in kernel number and fertile tillers number.

\subsection{Genetic Variability}

In trying to determine the extent to which variation in yield components are responsible for differences in yield among various cultivars, it must be borne in mind that overall variability depends on heritable and non-heritable components. While coefficients of variation measure the magnitude of variability present in a population, estimates of heritability and genetic advances are important preliminary steps in any breeding program as they provide information needed in designing the most effective breeding program and the relative practicability of selection. Genotypic variance, phenotypic variance, genotypic coefficient of variability (GCV), phenotypic coefficient of variability (PCV), broad sense heritability, genetic advance and genetic advance expressed as percentage of mean for 11 characters are presented in Table 7.

\subsection{Estimates of Heritability}

The results revealed considerable phenotypic and genotypic variances among the genotypes for the traits under consideration. In all traits a large portion of the phenotypic variance was accounted for by the genetic component and the contributions of genetic variance to phenotypic variance were more than $67 \%$ (Table 7). The estimates of GCV were high for number of kernels per main spike (35.24), grain yield per plant (26.04), biological yield per plant (22.86), grain filling period (19.40), fertile tillers number (16.28), and plant height (15.91). The remaining traits recorded moderate to low GCV estimates. The PCV values were higher than GCV values for all the traits which reflect the influence of environment on the expression of traits. The results of heritability indicated that moderate heritability values were recorded for number of tillers per plant and fertile tillers number, while high heritability estimates for other yield components (number of kernels per main spike and thousand kernel weight) (Table 8).

\subsection{Estimates of Expected Genetic Advance}

The expected genetic advance values for 11 characters of the genotypes evaluated is presented in Table 7 . These values are also expressed as percentage of the genotypes mean for each character so that comparison could be made among various characters, which had different units of measurement. High heritability along with high genetic advance is an important factor for predicting the resultant effect for selecting the best individuals. Number of kernels per main spike, grain yield per plant, biological yield per plant, plant height, grain filling period, thousand kernel weight and fertile tillers number had high heritability accompanied with high genetic advance, while maturity date, heading date, number of tillers per plant and harvest index had high heritability coupled with low genetic advance. 


\subsection{Genotypic and Phenotypic Correlations among Characters}

The phenotypic and genotypic correlations for morpho-agronomic traits are presented in Table 8. Number of kernels per main spike, which is the main component of grain yield, gave the highest positive significant phenotypic and genotypic association with grain yield per plant implying that improving this character could result in high grain yield. Since yield of grain is the product of number of spikes, number of kernels per spike, and kernel weight, all assume importance in efforts to attain new levels of productivity in barley. Number of productive tillers per plant had a highly significant genotypic correlation with grain yield but had low phenotypic correlation. The significant positive correlation of tillers per plant with yield per plant have been reported by Mondal et al. (1997) and that of number of grains per spike by Raut et al. (1995). Physio-morphological trait, i.e. plant height ranked second after yield components (number of kernels per main spike and number of productive tillers) in their positive associations with grain yield. A positive association between grain yield and grain filling period was obtained. On the contrary, grain yield had strong negative correlation $(\mathrm{P}<0.01)$ with days to heading.

\subsection{Multiple Correlation and Regression Analysis}

In order to determine the effect of morphological traits on grain yield, multiple correlation analyses were carried out (Table 9). The joint association through multiple correlations of all characters studied with yield was highly significant. Multiple correlations of characters (0.36), via. fertile tillers number and number of kernels per main spike, which were significant with grain yield were far from the multiple correlation of all characters $(0.96)$.

The significance of partial regression coefficients was also tested (Table 10). Partial regression analysis of grain yield on the basis of all yield components are given in Table 10a. Yield showed a significant partial regression coefficient with fertile tillers number, number of kernels per main spike and heading date. The selection of best regression equation done through backward elimination procedure revealed that fertile tillers number, number of kernels per main spike and heading date were the most effective variables contributing to the grain yield. The partial regression coefficients of fertile tillers number (0.47) and number of kernels per main spike $(0.05)$ were significant (Table 10b). The best regression equation to bring the maximum improvement in the grain yield has been shown in eq. 11 as follow:

$$
Y=0.376+0.47 X 1+0.05 X 4
$$

Where, $x 1$ : Fertile tillers number, $x 4$ : Number of kernels per main spike.

\section{Discussion}

The significant differences among barley genotypes in the investigation indicate the presence of genetic variability in the material used and provide a good opportunity for yield improvement. Grain yield and other characters exhibited stability across the seasons since the significance of genotype $\times$ environment interaction was not detected and the differences among genotypes were obvious (Table 4). This appears to show that further improvement through selection for all characters studied could be effective. High ratios of the genotypic variance to phenotypic variance for biological yield per plant, grain yield per plant, number of kernels per main spike, thousand kernel weight, plant height, heading date, maturity date and grain filling period indicate the existence of immense inherent variability that remains unaltered by environmental conditions among the genotypes, which in turn is more useful for exploitation in selection and hybridization programs.

Although the genotypic coefficient of variation revealed the extent of genetic variability present in the genotypes for various traits, it does not provide full scope to assess the variation that is heritable. Heritable variation is useful for permanent genetic improvement (Singh, 2000). The most important function of the heritability in the genetic study of quantitative characters is its predictive role to indicate the reliability of the phenotypic value as a guide to breeding value (Dabholkar 1992; Falconer and Mackay 1996). The genotypic coefficient of variation along with heritability estimates provide reliable estimates of the amount of genetic advance to be expected through phenotypic selection (Burton, 1952). High heritability estimates for grain yield, number of kernels per main spike, plant height and thousand kernel weight indicate a high response to selection in these traits (Shadakshari et al., 1995; Shan and Mishra, 1995) and this results were also reported by (Sachan and Singh, 2003; Siddique et al. 2006; Ali et al., 2008; Adewale et al., 2010; Rahim et al., 2010; Riaz-Ud-Din et al., 2010) which support the present findings. Heritability and genetic advance are important selection parameters. The estimate of genetic advance is more useful as a selection tool when considered jointly with heritability estimates (Johnson et al., 1955). The estimates of genetic advance help in understanding the type of gene action involved in the expression of various polygenic characters. High values of genetic advance are indicative of additive gene action whereas low values are indicative of non-additive gene action (Singh and Narayanan, 1993). Thus the heritability estimates will be reliable if accompanied by high genetic advance. 
High heritability accompanied with high genetic advance as percent of the mean in case of number of kernels per main spike, grain yield per plant, biological yield per plant, plant height, grain filling period, thousand kernel weight and fertile tillers number indicate that these are simply inherited traits and most likely the heritability is due to additive gene effects and selection may be effective in early generations for these traits. Similar findings have been reported by some authors (Dwivedi et al., 2002; Sharma and Garg, 2002; Ali et al., 2008). However, maturity date, heading date, number of tillers per plant and harvest index had high heritability coupled with low genetic advance indicates non-additive gene effects.

From the above discussion, kernel weight of main spike, grain yield per plant, number of kernels per main spike, biological yield per plant, and plant height were shown to have high to moderate genotypic variance, high to moderate heritability and greater genetic gain. Selection can therefore be based on these characters and their phenotypic expression would be a good indicator of their genotypic potentiality. The remaining traits recorded lower scores in the three genetic parameters considered in this study and therefore offered less scope for selection as they were much more under the influence of the environment. An understanding of inter-character correlation is essential to successful selection of useful genotypes from the whole population but intensive selection for any characteristic might result in losses in others (Lebsock and Amaya, 1969). The magnitude of the genotypic and phenotypic correlations and their utilization in the selection had been stated by a number of researchers (Van Oosteron and Acevedo, 1992; Gashaw, 2007; Ali et al., 2008). Genotypic correlation coefficient offers a measure of the genetic association between characteristics and may provide an important criterion of the selection procedures (Can and Yoshida, 1999). Genotypic correlation coefficient values were greater for most of the characters than their corresponding phenotypic correlation coefficient values, indicating inherent association of the characters. Positive significant associations were obtained between grain yield and plant height because these tall lines generally excelled in their capacity to support kernel growth by stem reserve mobilization (Blum et al., 1989). Therefore, selection for tall plants tends to increase grain yield per plant. The present study suggests that a positive association between grain yield and grain filling period and a negative association with days to heading were obtained. Previous studies have confirmed this result (Gebeyehou et al., 1982; Amin et al., 1992; Van Oosteron and Acevedo, 1992; Gashaw, 2007), which means that early heading genotypes with adequate grain filling period escape terminal moisture stress and, thus give better grain yield. The yield components exhibited varying trends of association among themselves. Plant height showed positive significant correlations with kernel weight per main spike. The significant positive correlation of plant height with kernel weight has been reported by Ali et al. (2008). To evaluate the correlation between variables, it is important to know this "magnitude" or "strength" as well as the significance of the correlation. It expresses the amount of common variation between the two variables. The estimate of determination $\left(\mathrm{R}^{2}\right)$ indicates that the total variability accounted by all the characters considered together was $96 \%$, whereas $36 \%$ of the total variability for yield per plant could be accounted if selection was based only on fertile tillers number and number of kernels per main spike indicating that more emphasis should be laid on the improvement of these two components for increasing the grain yield in barley.

\section{Conclusion}

The present study revealed that grain yield per plant had strong and positive genotypic correlation with fertile tillers number, and number of kernels per main spike. Multiple correlations indicated that the total variability accounted by these traits was $36.38 \%$. Regression analysis also indicated fertile tillers number and number of kernels per main spike as the most effective variables contributing to the grain yield. So, it is concluded that these two traits may be considered as the selection criteria for the improvement of grain barley.

\section{Acknowledgments}

We appreciate the International Center for Agricultural Research in the Dry Areas (ICARDA) and Al-Balqa Applied University for the support extended to this investigation.

\section{References}

Adewale, B.D., Okonji, C., Oyekanmi, A.A., Akintobi, D.A.C., \& Aremu, C.O. (2010). Genotypic variability and stability of some grain yield components of Cowpea. Afr. J. Agric. Res, 5 (9), 874-880.

Ali, Y., Atta, B.M., Akhter, J., Monneveux, P., \& Lateef, Z. (2008). Genetic variability, association and diversity studies in wheat (Triticum aesitum L.) germplasm. Pak. J. Bot, 40(5, 2087-2097.

Al-Jamali, A.F., Turk, M.A., \& Tawaha, A.M. (2002). Effect of ethephon spraying at three developmental stages of barley planted in arid and semi-arid Mediterranean locations. J Agron Crop Sci, 188, 254-259. http://dx.doi.org/10.1046/j.1439-037X.2002.00568.x 
Allard, R.W. (1960). Principles of plant breeding. John Wiley and Sons, New York.

Amin, M.R., Barma, N.C., \& Razzague, M.A. (1992). Variability, heritability, genetic advance and correlation study in some quantitative characters in durum wheat. Rachis News Lett, 11, 30-32.

Arega, G., Hussein M., \& Harjit, S. (2007). Selection criterion for improved grain yields in ethiopian durum wheat genotypes. African Crop Science Journal, 15 (1): 25 - 31.

Atta, B.M., Haq, M.A., \& Shah, T.M. (2008). Variation and inter relationships of quantitative traits in chickpea (Cicer arietinum L.). Pak J Bot, 40(2): 637-647.

Blum, A., Golan, G., Mayer, J., Sinmena, B., Shpiler, L., \& Burra, J. (1989). The drought response of landraces of wheat from the northern negev desert in Israel. Euphytica, 4: 87-96. http://dx.doi.org/10.1007/BF00037900

Burton, G.W. (1952). Quantitative inheritance in grasses .Proc. ${ }^{\text {th }}$. Intl. Grassland Congr. 1, 277-283.

Can, N.D., \& Yoshida, T. (1999). Genotypic and phenotypic variances and covariance's in early maturing grain sorghum in a double cropping. Plant Prod. Sci 2(1), 67-70. http://dx.doi.org/10.1626/pps.2.67

Cassman, K.G. (1999). Ecological intensification of cereal production systems: Yield potential, soil quality, and precision agriculture. Proc Nat Academy of Science, 96, 5952-5959. http://dx.doi.org/10.1073/pnas.96.11.5952

Comstock, R. R., \& Robinson, H.F. (1952). Genetic parameters, their estimation and significance, proc. $6^{\mathrm{TH}}$ international Grassland Congress.Vol. 1, Nat. publ. Co. Wash., D.C., U.S.A., pp : 248-291.

Dabholkar, A.R. (1992). Elements of biometrical genetics. Concept Publishing Company, New Delhi, India.

Dwivedi, A.N., Pawar, I.S., Shashi, M., \& Madan, S. (2002). Studies on variability parameters and character association among yield and quality attributing traits in wheat. Haryana Agric. Univ.J. Res, 32(2), 77-80.

Ehdaie, B., \& Waines, J.G. (1989). Genetic variation, heritability and path analysis in land races of bread wheat from South Western Iran. Euphytica, 41, 183-190.

Falconer, D.S. (1989). Introduction to quantitative genetics. ( $3^{\text {rd }}$ Ed) Logman Scientific and Technical, Logman House, Burnt Mill, Harlow, Essex, England.

Falconer, D.S., \& Mackay, T.F.C. (1996). Introduction to quantitative genetics. ${ }^{\text {th }}$ Edn., Benjamin Cummings, England, ISBN-10 : 0582243025.

FAO. (2009). Food and agriculture organization of the united nations, In: FAO Statistical Yearbook, Rome, Italy.

Gebeyehou, G., Knott, D.R., \& Baker, R.J. (1982). Rate and duration of grain filling in durum wheat cultivars. Crop Sci, 22, 337-340. http://dx.doi.org/10.2135/cropsci1982.0011183X002200020033x

Ifftikhar, J., Khalil, H., Abdul Bari., Sajid, Khan., \& Zada, I. (2009). Genetic variation for yield and yield components in rice. Journal of Agricultural and Biological Science, 4(6), 60-64.

Johnson, H.W, Robinson, H.E., \& Comstock, R.E. (1955). Estimates of genetic and environmental variability in soybean. Agron. J, 47, 314-318. http://dx.doi.org/10.2134/agronj1955.00021962004700070009x

Joshi, A.K., Sharma, G.S., \& Dhari, R. (1982). Variability and association of flag leaf area and other trait in wheat. Indian J Agric Sci, 52 (6), 351-355.

Kashiani, P., \& Saleh, G. (2010). Estimation of genetic correlations on sweet corn inbred lines using sas mixed model. American Journal of Agricultural and Biological Science, 5 (3), 309-314. http://dx.doi.org/10.3844/ajabssp.2010.309.314

Lebsock, K. L., \& Amaya, A. (1969). Variation and Covariation of Agronomic Traits in Durum Wheat. Crop Sci, 9, 372-375. http://dx.doi.org/10.2135/cropsci1969.0011183X000900030040x

Mary, S. S., \& Gopalan, A, (2006). Dissection of genetic attributes yield traits of fodder cowpea in F3 and F4. $J$ Applied Sci Res, 2, 805-808.

Miller, .PA., Williams, J.C., Robinson, H.F., \& Comstock, R.E. (1958). Estimates of genotypic and environmental variances and covariance's in Upland cotton and their implications in selection. Agronomy Journal, 50, 126-131. http://dx.doi.org/10.2134/agronj1958.00021962005000030004x

Mondal, A.B., Sadhu, D.P., \& Sarkar, K.K. (1997). Correlation and path analysis in bread wheat. Environ. Eco, 15(3), 537-539.

Rahim, M.A., Mia, A. A., Mahmud, F., Zeba, N., \& Afrin, K.S (2010). Genetic variability, character association and genetic divergence in Mungbean (Vigna radiataL. Wilczek). Plant Omic, 3(1), 1-6. 
Raut, S.K., Manjaya, J.G., Khorgade, P.W. (1995). Selection criteria in wheat (Triticum aestivum L.). PKV Res, 19(1), 17-20.

Riaz-Ud-Din, Subhani, G.M., Naeem, A., Makhdoom, H., \& Ur Rehman, A. (2010). Effect of temperature on development and grain formation in spring wheat. Pak. J. Bot, 42(2), 899-906.

Sachan, M.S., \& Singh, S.P. (2003). Genetics of yield and its components in durum wheat (Triticumdurum Desf.). $J$. Interacademicia, India 7(2), 140-143.

SAS Institute. (2002). SAS user's guide: Statistics version 9 for windows.SAS Institute., Carry, NC.

Shadakshari, Y. G., Virupahshappa, K., \& Shivasharikar, G. (1995). Genetic variability studies in the germplasm collections of sesamum (Sesamum indicum L.). Mysore Journal of Agricultural Science, 29, 133 -137.

Shan, G.S., \& Mishra, R.S. (1995). Genetic divergence in tomato. Mysore Journal of Agricultural Science, 29, $5-8$.

Sharma, A.K., \& Garg, D. (2002). Genetic variability in wheat (Triticum aestivum L.) crosses under different normal and saline environments. Annals Agric Res, 23(3), 497- 499.

Shukla, S., Bhargava, A., Chatterjee, A., Srivastava, A., \& Singh, S.P. (2006). Genotypic variability in vegetable amaranth (Amaranthus tricolor L.) for foliage yield and its contributing traits over successive cuttings and years. Euphytica, 151, 103-110. http://dx.doi.org/10.1007/s10681-006-9134-3

Siddique, M., Faisal, M., Malik, A., \& Awan, S.I. (2006). Genetic divergence, association and performance evaluation of different genotypes of mungbean (Vigna radiata). Int. J Agri. Biol, 8(6), 793-795.

Singh, B. D. (2000). Plant breeding: principles and methods. Kalyani Publishers, New Delhi.

Singh, P., \& Narayanan, S.S. (1993). Biometrical techniques in plant breeding. Kalyani, Publishers New Delhi.

Singh, R.K., \& Chaudhary, B.D. (1985). Biometrical Methods in Quantitative Analysis. kalayani Publishers. New Delhi.

Tawaha, A.M., \& Turk, M.A. (2002). Awnless barley (Hordeum vulagre L.) response to hand weeding and 2,4-D application at two growth stages under Mediterranean environment. Weed. Bio. Management, 2,163-168. http://dx.doi.org/10.1046/j.1445-6664.2002.00064.x

Turk, M.A., \& Tawaha, A.M. (2003). Weed control in cereal in Jordan. Crop Protection, 22, 239-246. http://dx.doi.org/10.1016/S0261-2194(02)00182-5

Turk, M.A., Tawaha, A.M., Samara, N. \& Allataifeh, N. (2003). The response of six row barley (Hordeum vulgare L.) to nitrogen fertilizer application and weed control methods in the absence of moisture stress. Pak J Agron, 2, $101-108$

Van Oosteron, E. J., \& Acevedo, E. (1992). Adaptation of Barley (Hordeum vulgare L.) to harsh Mediterranean environments. Euphytica, 62, 29-38. http://dx.doi.org/10.1007/BF00036084

Table 1. Number, name / cross pedigree, seed source, source number, and FAO status of the genotypes

\begin{tabular}{|l|l|l|l|l|l|}
\hline $\begin{array}{l}\text { Entry } \\
\text { No. }\end{array}$ & Name/Cross & Pedigree & Seed Source & $\begin{array}{l}\text { Source } \\
\text { No. }\end{array}$ & $\begin{array}{l}\text { FAO } \\
\text { Status* }\end{array}$ \\
\hline 1 & Harmal & - & CHECK05 & 26 & U \\
\hline 2 & Tipper/ICB-102854//Alpha/Durra & ICBH98-0441-0AP-6AP-0AP & BOLC06INC & 2 & U \\
\hline 3 & MRYT169/Mamluk//YEA389-3/YEA475-4 & ICBH97-0098-0AP-0AP-7AP-0AP & BOLC06INC & 3 & U \\
\hline 4 & Lignee131/ArabiAbiad/Mal1-4-3094-2 & ICBH92-0339-0AP-3AP-0AP-5AP-0AP & BOLC06INC & 7 & U \\
\hline 5 & WI2291/Roho//WI2269/3/Arta & ICB98-1035-0AP-42AP-0AP & BOLC06INC & 8 & U \\
\hline 6 & WI2291/Roho//WI2269/3/Arta & ICB98-1035-0AP-44AP-0AP & BOLC06INC & 9 & U \\
\hline 7 & WI2291/Roho//WI2269/3/Arta & ICB98-1035-0AP-44AP-0AP & BOLC06INC & 9 & U \\
\hline 8 & WI2291/Roho/WI2269/3/Arta & ICB98-1035-0AP-51AP-0AP & BOLC06INC & 11 & U \\
\hline 9 & WI2291/Roho//WI2269/3/Arta & ICB98-1035-0AP-53AP-0AP & BOLC06INC & 13 & U \\
\hline 10 & Matnan-01 & - & CHECK05 & 27 & U \\
\hline 11 & WI2291/Roho//WI2269/3/Arta & ICB98-1035-0AP-57AP-0AP & BOLC06INC & 14 & U \\
\hline 12 & WI2291/Roho//WI2269/3/Arta & ICB98-1035-0AP-78AP-0AP & BOLC06INC & 16 & U \\
\hline 13 & WI2291/Roho//WI2269/3/Arta & ICB98-1035-0AP-85AP-0AP & BOLC06INC & 17 & U \\
\hline 14 & WI2291/Roho//WI2269/3/Arta & ICB98-1035-0AP-86AP-0AP & BOLC06INC & 18 & U \\
\hline 15 & WI2291/Roho//WI2269/3/Arta & ICB98-1035-0AP-90AP-0AP & BOLC06INC & 19 & U \\
\hline
\end{tabular}




\begin{tabular}{|c|c|c|c|c|c|}
\hline 16 & WI2291/Roho//WI2269/3/Arta & ICB98-1035-0AP-93AP-0AP & BOLC06INC & 20 & $\mathrm{U}$ \\
\hline 17 & SLB39-39/H.spont.41-5 & $\begin{array}{l}\text { ICB87-1011-62AP- } \\
\text { 1BO-0AP-2APH- } \\
\text { 2AP-0AP-4AP-0A- } \\
\text { 0AP-7A-0AP-0AP }\end{array}$ & BOLC06INC & 24 & $\mathrm{U}$ \\
\hline 18 & SLB39-39/H.spont.41-5 & $\begin{array}{l}\text { ICB87-1011-62AP- } \\
\text { 1BO-0AP-2APH- } \\
\text { 2AP-0AP-4AP-0A- } \\
\text { 0AP-10-0AP-0AP }\end{array}$ & BOLC06INC & 25 & $\mathrm{U}$ \\
\hline 19 & Arar/H.spont.19-15//Arta & $\begin{array}{l}\text { ICB88-1271-19AP- } \\
\text { 5AP-1APH-0AP- } \\
\text { 4AP-0AP-7AP-0A- } \\
\text { 0AP-1A-0AP-0AP }\end{array}$ & BOLC06INC & 26 & $\mathrm{U}$ \\
\hline 20 & National_check & - & - & - & - \\
\hline 21 & Arar/H.spont.19-15//Arta & $\begin{array}{l}\text { ICB88-1271-19AP- } \\
\text { 5AP-1APH-0AP- } \\
\text { 4AP-0AP-7AP-0A- } \\
\text { 0AP-4A-0AP-0AP }\end{array}$ & BOLC06INC & 27 & $\mathrm{U}$ \\
\hline 22 & Arar/H.spont.19-15//Arta & $\begin{array}{l}\text { ICB88-1271-19AP- } \\
\text { 5AP-1APH-0AP- } \\
\text { 4AP-0AP-7AP-0A- } \\
\text { 0AP-5A-0AP-0AP }\end{array}$ & BOLC06INC & 28 & $\mathrm{U}$ \\
\hline 23 & Arar/H.spont.19-15//Arta & $\begin{array}{l}\text { ICB88-1271-19AP- } \\
\text { 5AP-1APH-0AP- } \\
\text { 4AP-0AP-7AP-0A- } \\
\text { 0AP-9A-0AP-0AP }\end{array}$ & BOLC06INC & 29 & $\mathrm{U}$ \\
\hline 24 & Arar/H.spont.19-15//Arta & $\begin{array}{l}\text { ICB88-1271-19AP- } \\
\text { 5AP-1APH-0AP- } \\
\text { 4AP-0AP-8AP-0A- } \\
\text { 0AP-7A-0AP-0AP }\end{array}$ & BOLC06INC & 30 & $\mathrm{U}$ \\
\hline 25 & Moroc9-75/Harmal & $\begin{array}{l}\text { ICB92-0809-47AP-0AP- } \\
\text { 10AP-0AP-0AP-6AP-0AP }\end{array}$ & BOLC06INC & 31 & $\mathrm{U}$ \\
\hline 26 & Moroc9-75/Harmal & $\begin{array}{l}\text { ICB92-0809-47AP-0AP-1AP } \\
\text {-0AP-0AP-4AP-0AP }\end{array}$ & BOLC06INC & 32 & $\mathrm{U}$ \\
\hline 27 & Moroc9-75/Harmal & $\begin{array}{l}\text { ICB92-0809-47AP-0AP- } \\
\text { 1AP-0AP-0AP-12AP-0AP }\end{array}$ & BOLC06INC & 33 & $\mathrm{U}$ \\
\hline 28 & H.spont.21-3/Arar84//WI2269/3/Sara & $\begin{array}{l}\text { ICB93-0644-0AP-11AP- } \\
\text { 0AP-0AP-12AP-0AP }\end{array}$ & BOLC06INC & 34 & $\mathrm{U}$ \\
\hline 29 & $\begin{array}{l}\text { ArabiAbiad/WI2291//Tadmor/4/H.spont.93- } \\
\text { 4/3/Roho//Alger/Ceres362-1-1 }\end{array}$ & $\begin{array}{l}\text { ICB93-0690-0AP-19AP- } \\
\text { 0AP-0AP-8AP-0AP }\end{array}$ & BOLC06INC & 35 & $\mathrm{U}$ \\
\hline 30 & Harmal & - & CHECK05 & 26 & $\mathrm{U}$ \\
\hline 31 & WI2291/Tipper & $\begin{array}{l}\text { ICB93-1156-0AP-4AP } \\
\text {-0AP-0AP-16AP-0AP }\end{array}$ & BOLC06INC & 36 & $\mathrm{U}$ \\
\hline 32 & $\begin{array}{l}\text { Akrash//WI2291/WI2269/3/WI2291/ } \\
\text { WI2269//WI2291/Bgs }\end{array}$ & $\begin{array}{l}\text { ICB94-0402-0AP-6A-0AP-0AP- } \\
\text { 8AP-0AP }\end{array}$ & BOLC06INC & 38 & $\mathrm{U}$ \\
\hline 33 & $\begin{array}{l}\text { Akrash//WI2291/WI2269/3/WI2291/ } \\
\text { WI2269//WI2291/Bgs }\end{array}$ & $\begin{array}{l}\text { ICB94-0402-0AP-6A-0AP-0AP- } \\
\text { 16AP-0AP }\end{array}$ & BOLC06INC & 39 & $\mathrm{U}$ \\
\hline 34 & $\begin{array}{l}\text { Akrash//WI2291/WI2269/3/WI2291/ } \\
\text { WI2269//WI2291/Bgs }\end{array}$ & $\begin{array}{l}\text { ICB94-0402-0AP-6A-0AP-0AP- } \\
\text { 19AP-0AP }\end{array}$ & BOLC06INC & 40 & $\mathrm{U}$ \\
\hline 35 & $\begin{array}{l}\text { Akrash//WI2291/WI2269/3/WI2291/ } \\
\text { WI2269//WI2291/Bgs }\end{array}$ & $\begin{array}{l}\text { ICB94-0402-0AP-7A-0AP-0AP- } \\
\text { 9AP-0AP }\end{array}$ & BOLC06INC & 41 & $\mathrm{U}$ \\
\hline 36 & $\begin{array}{l}\text { Akrash//WI2291/WI2269/3/WI2291/ } \\
\text { WI2269//WI2291/Bgs }\end{array}$ & $\begin{array}{l}\text { ICB94-0402-0AP-7A-0AP- } \\
\text { 0AP-10AP-0AP }\end{array}$ & BOLC06INC & 42 & $\mathrm{U}$ \\
\hline 37 & $\begin{array}{l}\text { Akrash//WI2291/WI2269/3/WI2291/ } \\
\text { WI2269//WI2291/Bgs }\end{array}$ & $\begin{array}{l}\text { ICB94-0402-0AP-7A-0AP- } \\
\text { 0AP-11AP-0AP }\end{array}$ & BOLC06INC & 43 & $\mathrm{U}$ \\
\hline 38 & $\begin{array}{l}\text { Akrash//WI2291/WI2269/3/WI2291/ } \\
\text { WI2269//WI2291/Bgs }\end{array}$ & $\begin{array}{l}\text { ICB94-0402-0AP-7A-0AP- } \\
\text { 0AP-12AP-0AP }\end{array}$ & BOLC06INC & 44 & $\mathrm{U}$ \\
\hline 39 & Mo.B1337/WI2291//Sls/Akrash-02 & $\begin{array}{l}\text { ICB94-0654-0AP-10-0AP- } \\
\text { 0AP-12AP-0AP }\end{array}$ & BOLC06INC & 46 & $\mathrm{U}$ \\
\hline 40 & Matnan-01 & - & CHECK05 & 27 & $\mathrm{U}$ \\
\hline
\end{tabular}




\begin{tabular}{|c|c|c|c|c|c|}
\hline 41 & $\begin{array}{l}\text { Akrash//WI2291/WI2269/3/Arar/19-3/ } \\
\text { /WI2291 }\end{array}$ & $\begin{array}{l}\text { ICB94-0671-0AP-1A-0AP- } \\
\text { 0AP-20AP-0AP }\end{array}$ & BOLC06INC & 47 & $\mathrm{U}$ \\
\hline 42 & ArabiAbiad/Arar/3/Arar/19-3//WI2291 & $\begin{array}{l}\text { ICB94-0681-0AP-5A-0AP- } \\
\text { 0AP-5AP-0AP }\end{array}$ & BOLC06INC & 49 & $\mathrm{U}$ \\
\hline 43 & ArabiAbiad/Arar/3/Arar/19-3//WI2291 & $\begin{array}{l}\text { ICB94-0681-0AP-5A-0AP- } \\
\text { 0AP-6AP-0AP }\end{array}$ & BOLC06INC & 50 & $\mathrm{U}$ \\
\hline 44 & Akrash//WI2291/WI2269/3/Sls/Akrash-02 & ICB94-0644-0AP-41AP-0AP & BOLC06INC & 54 & $\mathrm{U}$ \\
\hline 45 & $\begin{array}{l}\text { H.spont.41-1/Tadmor/4/Gloria'S'/Copal'S'/ } \\
\text { /Abn/3/Shyri }\end{array}$ & ICB97-0407-0AP-2AP-0AP & BOLC06INC & 56 & $\mathrm{U}$ \\
\hline 46 & $\begin{array}{l}\text { WI2269/Lignee131/3/SB73358-B-104-16- } \\
\text { 1-3//ER/Apm/5/ER/Apm } \\
\text { //Lignee131/4/ER/Apm/3/Arr/Esp//Alger } \\
\text { /Ceres362-1-1 }\end{array}$ & ICB98-0981-0AP-3AP-0AP & BOLC06INC & 57 & $\mathrm{U}$ \\
\hline 47 & $\begin{array}{l}\text { WI2269/Lignee131/3/SB73358-B-104-16 } \\
\text {-1-3//ER/Apm/5/ER/Apm } \\
\text { //Lignee131/4/ER/Apm/3/Arr/Esp//Alger/ } \\
\text { Ceres362-1-1 }\end{array}$ & ICB98-0981-0AP-5AP-0AP & BOLC06INC & 58 & $\mathrm{U}$ \\
\hline 48 & $\begin{array}{l}\text { Mo.B1337/WI2291//Bonita/Weeah/5/ER/ } \\
\text { Apm//Lignee131/4/ER/Apm/3/Arr/Esp// } \\
\text { Alger/Ceres362-1-1 }\end{array}$ & ICB98-0990-0AP-4AP-0AP & BOLC06INC & 59 & $\mathrm{U}$ \\
\hline 49 & SLB39-05/4/7028/2759/3/69-82//Ds/Apro & $\begin{array}{l}\text { ICB87-0588-10BO-1APH-0TR } \\
\text {-0AP-15AP-0AP-16AP-0AP }\end{array}$ & BOLC06INC & 60 & $\mathrm{U}$ \\
\hline 50 & National_check & - & - & - & - \\
\hline 51 & Viringa'S'//Hml-02/ArabiAbiad*2 & $\begin{array}{l}\text { ICB92-1453-0AP-10AP-4TR } \\
-0 \text { AP }\end{array}$ & BOLC06INC & 62 & $\mathrm{U}$ \\
\hline 52 & $\begin{array}{l}\text { Moroc9-75//WI2291/CI01387/3/H.spont.41 } \\
\text {-1/Tadmor }\end{array}$ & $\begin{array}{l}\text { ICB94-0342-38AP-0AP-7AP } \\
\text {-2TR-0AP }\end{array}$ & BOLC06INC & 63 & $\mathrm{U}$ \\
\hline 53 & ArabiAbiad/Arar//H.spont.41-5/Tadmor & $\begin{array}{l}\text { ICB94-0358-12AP-0AP-4AP } \\
\text {-1TR-0AP }\end{array}$ & BOLC06INC & 64 & $\mathrm{U}$ \\
\hline 54 & ArabiAbiad/Arar//H.spont.41-5/Tadmor & $\begin{array}{l}\text { ICB94-0358-12AP-0AP-7AP } \\
-4 \text { TR-0AP }\end{array}$ & BOLC06INC & 66 & $\mathrm{U}$ \\
\hline 55 & Arta/Zabad & ICB97-0282-0AP-23AP-15TR-0AP & BOLC06INC & 68 & $\mathrm{U}$ \\
\hline 56 & Arta/Zabad & ICB97-0282-0AP-23AP-18TR-0AP & BOLC06INC & 69 & $\mathrm{U}$ \\
\hline 57 & $\begin{array}{l}\text { SLB45-58/Arta/6/WI2291/Bgs/5/Cq/Cm// } \\
\text { Apm/3/12410/4/Gizeh134-2L }\end{array}$ & ICB97-0385-0AP-25AP-14TR-0AP & BOLC06INC & 70 & $\mathrm{U}$ \\
\hline 58 & $\begin{array}{l}\text { Cerise/Lignee1479//Moroc9-75/PmB/3/JLB37 } \\
\text {-74/H.spont.41-5// JLB37-74/H.spont.41-5 }\end{array}$ & ICB97-0402-0AP-11AP-2TR-0AP & BOLC06INC & 71 & $\mathrm{U}$ \\
\hline 59 & Rum//Alanda/Hamra & ICB98-0726-0AP-16AP-0AP & BOLC06INC & 73 & $\mathrm{U}$ \\
\hline 60 & Harmal & - & CHECK05 & 26 & $\mathrm{U}$ \\
\hline 61 & Rum//Alanda/Hamra & ICB98-0726-0AP-27AP-0AP & BOLC06INC & 74 & $\mathrm{U}$ \\
\hline 62 & Rum//Alanda/Hamra & ICB98-0726-0AP-69AP-0AP & BOLC06INC & 76 & $\mathrm{U}$ \\
\hline 63 & Rum//Alanda/Hamra & ICB98-0726-0AP-79AP-0AP & BOLC06INC & 78 & $\mathrm{U}$ \\
\hline 64 & Rum//Alanda/Hamra & ICB98-0726-0AP-86AP-0AP & BOLC06INC & 80 & $\mathrm{U}$ \\
\hline 65 & Rum//Alanda/Hamra & ICB98-0726-0AP-91AP-0AP & BOLC06INC & 81 & $\mathrm{U}$ \\
\hline 66 & Rum//Alanda/Hamra & ICB98-0726-0AP-100AP-0AP & BOLC06INC & 82 & $\mathrm{U}$ \\
\hline 67 & Rum/Manal & ICB98-0739-0AP-1AP-0AP & BOLC06INC & 85 & $\mathrm{U}$ \\
\hline 68 & Rum/Manal & ICB98-0739-0AP-6AP-0AP & BOLC06INC & 86 & $\mathrm{U}$ \\
\hline 69 & Beecher & Sel.7TR-1TR-0AP & BOLC06INC & 87 & - \\
\hline 70 & Matnan-01 & - & CHECK05 & 27 & \\
\hline 71 & Beecher & Sel.7TR-2TR-0AP & BOLC06INC & 88 & - \\
\hline 72 & Beecher & Sel.12TR-3TR-0AP & BOLC06INC & 89 & - \\
\hline 73 & $\begin{array}{l}\text { Aths/Lignee686/4/Avt/Attiki//Aths/3/Giza121 } \\
\text { /Pue }\end{array}$ & ICB95-0315-0AP-1AP-0AP & BOLC06INC & 91 & $\mathrm{U}$ \\
\hline 74 & $\begin{array}{l}\text { Mari/Aths*2//Avt/Attiki/3/Aths/Lignee686/4/ } \\
\text { Manal }\end{array}$ & ICB96-0856-0AP-14AP-0AP & BOLC06INC & 92 & $\mathrm{U}$ \\
\hline 75 & $\begin{array}{l}\text { Mari/Aths*2//Avt/Attiki/3/Aths/Lignee686/ } \\
\text { 4/Arar//Hr/Nopal }\end{array}$ & ICB96-0866-0AP-6AP-0AP & BOLC06INC & 93 & $\mathrm{U}$ \\
\hline 76 & Acc\#116132-Coll\#89023-11/Malouh & ICB98-0433-0AP-11AP-0AP & BOLC06INC & 96 & $\mathrm{U}$ \\
\hline 77 & Rhn-03/3/Api/CM67//Aths*3/4/Alanda-01 & ICB98-0446-0AP-8AP-0AP & BOLC06INC & 97 & $\mathrm{U}$ \\
\hline
\end{tabular}




\begin{tabular}{|c|c|c|c|c|c|}
\hline 78 & $\begin{array}{l}\text { Lignee527/NK1272//Alanda/3/Arbayan-01// } \\
\text { M6/Robur-35-6-3 }\end{array}$ & ICB98-0817-0AP-13AP-0AP & BOLC06INC & 98 & $\mathrm{U}$ \\
\hline 79 & Rhn-03//Arar/Lignee527 & ICB98-0006-0AP-20AP-0AP & BOLC06INC & 99 & $\mathrm{U}$ \\
\hline 80 & National_check & - & - & - & - \\
\hline 81 & $\begin{array}{l}\text { Khardal/3/Lignee527/Chn-01//Asher/5 } \\
\text { /CompCr229//As46/Pro/3/Srs/4/Bda }\end{array}$ & ICB98-0027-0AP-18AP-0AP & BOLC06INC & 100 & $\mathrm{U}$ \\
\hline 82 & $\begin{array}{l}\text { 80-5145/N-Acc4000-301-80//RWA-M54/ } \\
\text { 6/Rhn-03/Asse/5/U.Sask.1766/Api//Cel/3/Weeah } \\
\text { /4/Lignee527/NK1272 }\end{array}$ & ICB98-0033-0AP-15AP-0AP & BOLC06INC & 101 & $\mathrm{U}$ \\
\hline 83 & Rhn-03/3/Sutter//Sutter*2/Numar & ICB98-0056-0AP-1AP-0AP & BOLC06INC & 102 & $\mathrm{U}$ \\
\hline 84 & Rhn-03/4/Rhn-08/3/DeirAlla106//DL71/Strain205 & ICB98-0859-0AP-7AP-0AP & BOLC06INC & 103 & $\mathrm{U}$ \\
\hline 85 & $\begin{array}{l}\text { Centinela/2*Calicuchima/5/Alanda-02/4/ } \\
\text { Arizona5908/Aths//Asse/3/F208-74 }\end{array}$ & ICB98-0922-0AP-1AP-0AP & BOLC06INC & 105 & $\mathrm{U}$ \\
\hline 86 & Hamra/Lignee527/Rhn/3/Harra & ICB98-1221-0AP-4AP-0AP & BOLC06INC & 107 & $\mathrm{U}$ \\
\hline 87 & Tunisia/3/Lignee527/Chn-01//Lignee527/NK1272 & ICB98-1254-0AP-1AP-0AP & BOLC06INC & 109 & $\mathrm{U}$ \\
\hline 88 & Alanda/Hamra//M192 & ICB98-1210-0AP-3AP-0AP & BOLC06INC & 110 & $\mathrm{U}$ \\
\hline 89 & Carina/WI2291//Tilga & ICB02-1000-0AP & BOLC06INC & 111 & $\mathrm{U}$ \\
\hline 90 & Harmal & - & CHECK05 & 26 & $\mathrm{U}$ \\
\hline 91 & Carina/WI2291//WI3180 & ICB02-1060-0AP & BOLC06INC & 112 & $\mathrm{U}$ \\
\hline 92 & $\begin{array}{l}\text { Arda/Quinn/5/Roho/4/Zanbaka/3/ER } \\
\text { /Apm//Lignee131 }\end{array}$ & ICB02-1126-0AP & BOLC06INC & 113 & $\mathrm{U}$ \\
\hline 93 & Rhn-03//Lignee527/NK1272/3/Rum & ICB02-1509-0AP & BOLC06INC & 115 & $\mathrm{U}$ \\
\hline 94 & Roho//Alger/Ceres362-1-1/3/Kantara/4/Bowman & ICB93-0791-10AP-0AP-19AP-0AP & BOM06INC & 26 & $\mathrm{U}$ \\
\hline 95 & $\begin{array}{l}\text { Zabad/5/Sfa-02/3/RM1508/Por//WI2269/4/Roho } \\
\text { /Arabi Abiad }\end{array}$ & ICB96-0555-11AP-1TR-0AP & BOM06INC & 36 & $\mathrm{U}$ \\
\hline 96 & Clipper//WI2291*2/WI2269 & ICB97-0139-0AP-9AP-90TR-0AP & BOM06INC & 44 & $\mathrm{U}$ \\
\hline 97 & Matnan-01 & - & CHECK05 & 27 & $\mathrm{U}$ \\
\hline 98 & National_check (Rum) & - & - & - & - \\
\hline
\end{tabular}

Table 2. Distribution of rainfall and temperature regimes during the seasons

\begin{tabular}{|l|c|c|c|c|}
\hline \multirow{2}{*}{ Month } & \multicolumn{2}{|c|}{ Rainfall $(\mathrm{mm})$} & \multicolumn{2}{c|}{ Temperature $^{\circ} \mathrm{C}$} \\
\cline { 2 - 5 } & $2005 / 2006$ & $2006 / 2007$ & $2005 / 2006$ & $2006 / 2007$ \\
\hline December & 71.1 & 20.8 & 9.85 & 10.12 \\
\hline January & 62.8 & 62.2 & 9.1 & 10.12 \\
\hline February & 87.9 & 102.1 & 11.2 & 11.54 \\
\hline March & 4.5 & 51.3 & 11.65 & 11.64 \\
\hline April & 35.5 & 31 & 15.2 & 14.56 \\
\hline May & 0 & 9.4 & 22.2 & 23.2 \\
\hline June & 0 & 0 & 23.7 & 24.2 \\
\hline Total & 261.8 & 276.8 & & \\
\hline
\end{tabular}

Table 3. Analysis of variance form applied for combined data of two seasons

\begin{tabular}{|l|l|l|l|}
\hline Source of variation & $\mathrm{df}$ & $\mathrm{MS}$ & Expected MS \\
\hline Season (s) & $\mathrm{s}-1$ & - & - \\
\hline Rep. within season & $\mathrm{s}(\mathrm{r}-1)$ & - & - \\
\hline Cultivars (V) & $\mathrm{g}-1$ & $\mathrm{MS} 1$ & $\sigma_{\mathrm{e}}^{2}+\sigma_{\mathrm{gs}}^{2}+\mathrm{sr} \sigma_{\mathrm{g}}^{2}$ \\
\hline $\mathrm{V} \times \mathrm{S}$ & $(\mathrm{s}-1)(\mathrm{g}-1)$ & $\mathrm{MS} 2$ & $\sigma_{\mathrm{e}}^{2}+\mathrm{r} \sigma_{\mathrm{gs}}^{2}$ \\
\hline Pooled error & $\mathrm{S}(\mathrm{r}-1)(\mathrm{g}-1)$ & $\mathrm{MS} 3$ & $\sigma_{\mathrm{e}}^{2}$ \\
\hline
\end{tabular}


Table 4a. Analysis of variance for biological yield per plant, grain yield per plant (GY), harvest index per plant $(\mathrm{HI})$, tiller number $(\mathrm{TN})$, fertile tillers number $(\mathrm{FTN})$, number of kernels per main spike $(\mathrm{KN})$, thousand kernel weight (TKW), plant height (PH), heading date (HD), maturity date (MD) and grain filling period (GFP) of 86 barley genotypes grown under field conditions

\begin{tabular}{|l|l|l|l|l|l|l|l|l|}
\hline \multirow{2}{*}{ Source of variance } & \multicolumn{7}{|c|}{ Mean square } \\
\cline { 2 - 9 } & BY & GY & HI & TN & FTN & KN & TKW & PH \\
\hline Season (S) & 0.01 & 0.47 & 318.34 & $3^{* *}$ & $2.08^{* *}$ & $333.75^{* *}$ & 16.52 & $449.31^{* *}$ \\
\hline Rep. within season & $34.68^{* *}$ & $7.68^{* *}$ & $716.41^{* *}$ & $7.82^{* *}$ & $3.32^{* *}$ & 6.03 & 4.35 & $40.61^{* *}$ \\
\hline Cultivars (V) & $15.76^{* *}$ & $3.77^{* *}$ & $209.58^{* *}$ & $1.50^{* *}$ & $1.30^{* *}$ & $661.52^{* *}$ & $330.25^{* *}$ & $635.93^{* *}$ \\
\hline V $\times$ S & 0.75 & 0.01 & 39.88 & 0.48 & 0.33 & 7.92 & 17.67 & 11.46 \\
\hline Pooled error & 1.91 & 0.80 & 101.07 & 0.42 & 0.31 & 10.10 & 20.23 & 11.57 \\
\hline * Significant at the 0.05 probability level. & \multicolumn{9}{|l|}{} \\
\hline
\end{tabular}

Table 4b. Analysis of variance for biological yield per plant, grain yield per plant (GY), harvest index per plant $(\mathrm{HI})$, tiller number $(\mathrm{TN})$, fertile tillers number $(\mathrm{FTN})$, number of kernels per main spike $(\mathrm{KN})$, thousand kernel weight (TKW), plant height (PH), heading date (HD), maturity date (MD) and grain filling period (GFP) of 86 barley genotypes grown under field conditions

\begin{tabular}{|l|l|l|l|}
\hline \multirow{2}{*}{ Source of variance } & \multicolumn{3}{|c|}{ Mean square } \\
\cline { 2 - 4 } & HD & MD & GFP \\
\hline Season (S) & $187.91^{* *}$ & $848.88^{* *}$ & $238.01^{* *}$ \\
\hline Rep. within season & $22.11^{* *}$ & $164.26^{* *}$ & $84.86^{* *}$ \\
\hline Cultivars (V) & $138.06^{* *}$ & $253.52^{* *}$ & $177.33^{* *}$ \\
\hline V $\times$ S & 3.68 & 13.70 & 13.51 \\
\hline Pooled error & 3.65 & 11.14 & 13.70 \\
\hline * Significant at the 0.05 probability level. \\
\hline
\end{tabular}

Table 5. Variation for 11 characters in 86 barley genotypes and mean values of check cultivars

\begin{tabular}{|c|c|c|c|c|c|c|c|c|}
\hline \multirow{2}{*}{ Variable } & \multirow{2}{*}{ Range } & \multirow{2}{*}{ Mean \pm SE } & \multirow{2}{*}{$\begin{array}{c}\text { Std } \\
\text { Dev }\end{array}$} & \multirow{2}{*}{$\begin{array}{c}\text { F. values for } \\
\text { genotype }\end{array}$} & $\begin{array}{c}\text { LSD } \\
(\text { P-0.05 })\end{array}$ & \multicolumn{3}{|c|}{ Check cultivars } \\
\cline { 7 - 9 } & & & & & Rum & Harmal & Matnan \\
\hline BY & $2.00-14.25$ & $6.92 \pm 0.79$ & 02.06 & $08.24^{* *}$ & 01.57 & 6.66 & 6.32 & 7.59 \\
\hline GY & $0.58-7.65$ & $3.04 \pm 0.51$ & 01.09 & $04.72^{* *}$ & 01.02 & 2.99 & 2.78 & 3.41 \\
\hline HI & $9.5-84.4$ & $44.23 \pm 5.80$ & 10.65 & $00.39^{* *}$ & 11.42 & 44.88 & 44.35 & 45.94 \\
\hline TN & $1-6$ & $03.11 \pm 0.37$ & 00.82 & $03.63^{* *}$ & 00.73 & 02.75 & 03.38 & 03.00 \\
\hline FTN & $1-5$ & $02.47 \pm 0.32$ & 00.71 & $04.28^{* *}$ & 00.63 & 02.17 & 02.75 & 02.38 \\
\hline KN & $10-59$ & $29.62 \pm 1.83$ & 10.86 & $65.45^{* *}$ & 03.61 & 33.71 & 21.51 & 29.13 \\
\hline TKW & $24.97-79.20$ & $48.34 \pm 2.59$ & 08.42 & $16.33^{* *}$ & 05.11 & 50.79 & 51.44 & 45.44 \\
\hline PH & $39-91$ & $64.11 \pm 1.96$ & 10.76 & $54.95^{* *}$ & 03.87 & 62.25 & 66.33 & 61.83 \\
\hline HD & $106-139$ & $116.12 \pm 1.10$ & 05.13 & $37.80^{* *}$ & 02.17 & 116.75 & 112.25 & 119.04 \\
\hline MD & $123-178$ & $143.05 \pm 1.92$ & 07.36 & $22.74^{* *}$ & 03.79 & 141.92 & 140.79 & 148.17 \\
\hline GFP & $12-48$ & $26.93 \pm 2.14$ & 06.44 & $13.74^{* *}$ & 04.21 & 25.71 & 28.54 & 29.13 \\
\hline
\end{tabular}


Table 6a. Mean values of grain yield components of examined genotypes of barley

\begin{tabular}{|c|c|c|c|c|c|c|c|c|}
\hline Entry No. & Name & BY & GY & $\mathrm{HI}$ & $\mathrm{TN}$ & FTN & $\mathrm{KN}$ & KW \\
\hline 1 & Harmal & 05.31 & 2.62 & 49.39 & 2.67 & 2.67 & 18 & 48.72 \\
\hline 2 & Tipper/ICB-102854//Alpha/Durra & 06.12 & 1.83 & 29.87 & 3.33 & 1.67 & 21 & 38.51 \\
\hline 3 & MRYT169/Mamluk//YEA389-3/YEA475-4 & 05.45 & 1.85 & 33.96 & 3.00 & 2.17 & 17 & 39.66 \\
\hline 4 & Lignee131/ArabiAbiad//Mal1-4-3094-2 & 04.31 & 01.72 & 39.95 & 1.67 & 1.67 & 17 & 28.63 \\
\hline 5 & WI2291/Roho//WI2269/3/Arta & 06.85 & 03.06 & 44.68 & 3.67 & 2.67 & 25 & 49.06 \\
\hline 6 & WI2291/Roho//WI2269/3/Arta & 06.83 & 02.48 & 36.37 & 3.00 & 2.67 & 21 & 37.21 \\
\hline 7 & WI2291/Roho//WI2269/3/Arta & 06.46 & 2.31 & 35.75 & 3.33 & 2.33 & 15 & 49.05 \\
\hline 8 & WI2291/Roho//WI2269/3/Arta & 06.13 & 3.11 & 50.73 & 3.33 & 2.50 & 23 & 59.11 \\
\hline 9 & WI2291/Roho//WI2269/3/Arta & 03.77 & 02.20 & 58.22 & 3.00 & 2.17 & 15 & 52.04 \\
\hline 10 & Matnan-01 & 03.97 & 2.11 & 53.15 & 3.17 & 1.67 & 30 & 41.66 \\
\hline 11 & WI2291/Roho//WI2269/3/Arta & 03.22 & 01.87 & 58.12 & 2.33 & 1.50 & 23 & 48.12 \\
\hline 12 & WI2291/Roho//WI2269/3/Arta & 04.83 & 2.87 & 59.39 & 3.50 & 2.33 & 24 & 43.52 \\
\hline 13 & WI2291/Roho//WI2269/3/Arta & 04.97 & 2.59 & 52.24 & 2.67 & 2.00 & 25 & 50.31 \\
\hline 14 & WI2291/Roho//WI2269/3/Arta & 04.28 & 02.40 & 55.93 & 2.67 & 2.17 & 22 & 54.31 \\
\hline 15 & WI2291/Roho//WI2269/3/Arta & 05.04 & 2.41 & 47.75 & 2.67 & 1.83 & 24 & 53.25 \\
\hline 16 & WI2291/Roho//WI2269/3/Arta & 05.63 & 02.54 & 45.21 & 3.33 & 2.33 & 22 & 47.38 \\
\hline 17 & SLB39-39/H.spont.41-5 & 05.62 & 02.34 & 41.53 & 3.17 & 2.33 & 20 & 62.55 \\
\hline 18 & SLB39-39/H.spont.41-5 & 05.87 & 2.77 & 47.18 & 3.17 & 2.50 & 28 & 43.49 \\
\hline 19 & Arar/H.spont.19-15//Arta & 05.73 & 2.94 & 51.34 & 4.17 & 3.33 & 24 & 38.80 \\
\hline 20 & National_check & 05.77 & 2.75 & 47.58 & 2.67 & 1.50 & 36 & 52.19 \\
\hline 21 & Arar/H.spont.19-15//Arta & 05.15 & 2.53 & 49.17 & 3.00 & 2.50 & 25 & 37.69 \\
\hline 22 & Arar/H.spont.19-15//Arta & 05.11 & 2.64 & 51.75 & 2.83 & 2.17 & 25 & 46.64 \\
\hline 23 & Arar/H.spont.19-15//Arta & 03.99 & 1.94 & 48.61 & 2.83 & 2.33 & 23 & 38.19 \\
\hline 24 & Arar/H.spont.19-15//Arta & 05.21 & 2.12 & 40.59 & 2.83 & 2.33 & 23 & 37.54 \\
\hline 25 & Moroc9-75/Harmal & 04.79 & 2.37 & 49.46 & 2.67 & 2.00 & 21 & 54.03 \\
\hline 26 & Moroc9-75/Harmal & 08.08 & 3.37 & 41.68 & 3.50 & 3.17 & 22 & 56.79 \\
\hline 27 & Moroc9-75/Harmal & 05.16 & 2.56 & 49.63 & 2.83 & 2.33 & 22 & 55.56 \\
\hline 28 & H.spont.21-3/Arar84//WI2269/3/Sara & 07.51 & 2.74 & 36.43 & 4.00 & 3.00 & 22 & 50.46 \\
\hline 29 & $\begin{array}{l}\text { ArabiAbiad/WI2291//Tadmor/4/H.spont.93-4/3/Roho } \\
\text { //Alger/Ceres362-1-1 }\end{array}$ & 07.07 & 3.02 & 42.68 & 3.67 & 3.50 & 20 & 52.15 \\
\hline 30 & Harmal & 06.61 & 2.90 & 43.81 & 3.67 & 2.83 & 22 & 55.72 \\
\hline 31 & WI2291/Tipper & 06.70 & 2.76 & 41.15 & 3.50 & 2.67 & 25 & 50.46 \\
\hline 32 & Akrash//WI2291/WI2269/3/WI2291/WI2269//WI2291/Bgs & 06.38 & 2.98 & 46.68 & 2.83 & 2.50 & 21 & 54.03 \\
\hline 33 & Akrash//WI2291/WI2269/3/WI2291/WI2269//WI2291/Bgs & 06.36 & 2.59 & 40.79 & 3.00 & 2.17 & 22 & 52.29 \\
\hline 34 & Akrash//WI2291/WI2269/3/WI2291/WI2269//WI2291/Bgs & 06.86 & 2.77 & 40.38 & 2.67 & 2.17 & 24 & 49.37 \\
\hline 35 & Akrash//WI2291/WI2269/3/WI2291/WI2269//WI2291/Bgs & 05.45 & 02.28 & 41.89 & 3.00 & 2.17 & 23 & 48.50 \\
\hline 36 & Akrash//WI2291/WI2269/3/WI2291/WI2269//WI2291/Bgs & 06.89 & 2.68 & 38.95 & 3.83 & 3.33 & 25 & 42.74 \\
\hline 37 & Akrash//WI2291/WI2269/3/WI2291/WI2269//WI2291/Bgs & 05.15 & 2.36 & 45.87 & 2.83 & 2.17 & 24 & 44.45 \\
\hline 38 & Akrash//WI2291/WI2269/3/WI2291/WI2269//WI2291/Bgs & 07.69 & 3.83 & 49.74 & 3.50 & 2.83 & 24 & 49.39 \\
\hline 39 & Mo.B1337/WI2291//Sls/Akrash-02 & 07.23 & 3.33 & 45.99 & 3.17 & 2.50 & 22 & 57.97 \\
\hline 40 & Matnan-01 & 07.77 & 3.41 & 43.87 & 3.17 & 2.50 & 38 & 35.49 \\
\hline 41 & Akrash//WI2291/WI2269/3/Arar/19-3//WI2291 & 06.24 & 2.51 & 40.23 & 2.83 & 2.33 & 25 & 55.54 \\
\hline 42 & ArabiAbiad/Arar/3/Arar/19-3//WI2291 & 07.26 & 3.20 & 44.01 & 3.00 & 2.50 & 24 & 57.44 \\
\hline 43 & ArabiAbiad/Arar/3/Arar/19-3//WI2291 & 06.49 & 2.51 & 38.63 & 2.83 & 2.17 & 25 & 57.40 \\
\hline 44 & Akrash//WI2291/WI2269/3/Sls/Akrash-02 & 06.32 & 02.53 & 39.99 & 3.00 & 2.33 & 27 & 46.79 \\
\hline 45 & H.spont.41-1/Tadmor/4/Gloria'S'/Copal'S'//Abn/3/Shyri & 05.11 & 2.09 & 40.81 & 2.67 & 2.17 & 16 & 36.11 \\
\hline 46 & $\begin{array}{l}\text { WI2269/Lignee131/3/SB73358-B-104-16-1-3//ER/Apm/ 5/ER } \\
\text { /Apm//Lignee131/4/ER/Apm/3/Arr/Esp//Alger/Ceres362-1-1 }\end{array}$ & 04.40 & 1.78 & 40.57 & 3.00 & 2.50 & 17 & 29.90 \\
\hline 47 & $\begin{array}{l}\text { WI2269/Lignee131/3/SB73358-B-104-16-1-3//ER/Apm/5/ER } \\
\text { /Apm//Lignee131/4/ER/Apm/3/Arr/Esp//Alger/Ceres362-1-1 }\end{array}$ & 05.28 & 2.15 & 40.62 & 2.50 & 2.17 & 22 & 41.53 \\
\hline 48 & $\begin{array}{l}\text { Mo.B1337/WI2291//Bonita/Weeah/5/ER/Apm// } \\
\text { Lignee131/4/ER/Apm/3/Arr/Esp//Alger/Ceres362-1-1 }\end{array}$ & 05.85 & 2.62 & 44.82 & 2.67 & 2.17 & 23 & 63.57 \\
\hline 49 & SLB39-05/4/7028/2759/3/69-82//Ds/Apro & 06.95 & 2.88 & 41.44 & 2.83 & 2.33 & 27 & 57.63 \\
\hline
\end{tabular}




\begin{tabular}{|c|c|c|c|c|c|c|c|c|}
\hline 50 & National_check & 06.77 & 02.93 & 43.22 & 2.67 & 2.33 & 37 & 47.77 \\
\hline 51 & Viringa'S'//Hml-02/ArabiAbiad*2 & 07.97 & 2.69 & 33.76 & 3.00 & 2.00 & 23 & 49.53 \\
\hline 52 & Moroc9-75//WI2291/CI01387/3/H.spont.41-1/Tadmor & 07.78 & 2.98 & 38.39 & 3.50 & 2.33 & 22 & 45.96 \\
\hline 53 & ArabiAbiad/Arar//H.spont.41-5/Tadmor & 08.14 & 3.26 & 40.04 & 3.17 & 2.50 & 27 & 54.55 \\
\hline 54 & ArabiAbiad/Arar//H.spont.41-5/Tadmor & 07.53 & 03.18 & 42.23 & 3.17 & 2.83 & 22 & 50.05 \\
\hline 55 & Arta/Zabad & 08.64 & 04.08 & 47.27 & 4.50 & 3.33 & 22 & 61.55 \\
\hline 56 & Arta/Zabad & 07.75 & 3.12 & 40.26 & 3.67 & 2.50 & 26 & 49.32 \\
\hline 57 & $\begin{array}{l}\text { SLB45-58/Arta/6/WI2291/Bgs/5/Cq/Cm//Apm/ } \\
\text { 3/12410/4/Gizeh134-2L }\end{array}$ & 06.24 & 2.59 & 41.55 & 2.83 & 1.83 & 24 & 48.01 \\
\hline 58 & $\begin{array}{l}\text { Cerise/Lignee1479//Moroc9-75/PmB/3/JLB37-74 } \\
\text { /H.spont.41-5// JLB37-74/H.spont.41-5 }\end{array}$ & 07.17 & 2.88 & 40.16 & 3.17 & 2.33 & 18 & 55.47 \\
\hline 59 & Rum//Alanda/Hamra & 08.74 & 4.31 & 49.29 & 2.83 & 2.17 & 52 & 52.06 \\
\hline 60 & Harmal & 06.53 & 2.92 & 44.79 & 3.50 & 2.67 & 18 & 60.18 \\
\hline 61 & Rum//Alanda/Hamra & 07.81 & 3.81 & 48.80 & 2.83 & 2.50 & 51 & 50.43 \\
\hline 62 & Rum//Alanda/Hamra & 07.36 & 3.31 & 44.99 & 2.83 & 2.50 & 45 & 41.79 \\
\hline 63 & Rum//Alanda/Hamra & 11.34 & 4.95 & 43.69 & 3.00 & 2.83 & 55 & 52.78 \\
\hline 64 & Rum//Alanda/Hamra & 07.20 & 03.12 & 43.28 & 2.67 & 2.33 & 38 & 45.87 \\
\hline 65 & Rum//Alanda/Hamra & 08.75 & 4.38 & 50.08 & 2.83 & 2.33 & 53 & 55.82 \\
\hline 66 & Rum//Alanda/Hamra & 06.59 & 2.36 & 35.75 & 2.50 & 1.83 & 36 & 39.36 \\
\hline 67 & Rum/Manal & 07.87 & 3.02 & 38.33 & 2.67 & 2.33 & 46 & 36.07 \\
\hline 68 & Rum/Manal & 08.49 & 3.74 & 44.06 & 2.83 & 2.33 & 41 & 54.39 \\
\hline 69 & Beecher & 07.68 & 3.24 & 42.14 & 2.67 & 2.33 & 43 & 40.74 \\
\hline 70 & Matnan-01 & 08.45 & 3.42 & 40.45 & 2.83 & 2.67 & 35 & 47.99 \\
\hline 71 & Beecher & 08.42 & 3.86 & 45.87 & 3.33 & 2.33 & 35 & 59.55 \\
\hline 72 & Beecher & 08.62 & 03.42 & 39.69 & 3.33 & 2.33 & 45 & 55.32 \\
\hline 73 & Aths/Lignee686/4/Avt/Attiki//Aths/3/Giza121/Pue & 08.73 & 3.86 & 44.18 & 3.17 & 2.67 & 42 & 36.06 \\
\hline 74 & Mari/Aths*2//Avt/Attiki/3/Aths/Lignee686/4/Manal & 07.99 & 2.38 & 29.85 & 3.17 & 2.17 & 45 & 38.57 \\
\hline 75 & Mari/Aths*2//Avt/Attiki/3/Aths/Lignee686/4/Arar//Hr/Nopal & 08.57 & 03.83 & 44.68 & 3.33 & 2.67 & 45 & 43.41 \\
\hline 76 & Acc\#116132-Coll\#89023-11/Malouh & 09.62 & 05.07 & 52.66 & 3.67 & 3.50 & 43 & 51.68 \\
\hline 77 & Rhn-03/3/Api/CM67//Aths*3/4/Alanda-01 & 06.79 & 03.41 & 50.20 & 3.00 & 2.67 & 40 & 46.24 \\
\hline 78 & Lignee527/NK1272//Alanda/3/Arbayan-01//M6/Robur-35-6-3 & 09.69 & 04.36 & 45.00 & 3.83 & 3.33 & 47 & 45.59 \\
\hline 79 & Rhn-03//Arar/Lignee527 & 10.69 & 04.97 & 46.53 & 3.00 & 2.17 & 45 & 42.80 \\
\hline 80 & National_check & 07.19 & 03.37 & 46.83 & 3.17 & 2.50 & 34 & 50.22 \\
\hline 81 & $\begin{array}{l}\text { Kharda1/3/Lignee527/Chn-01//Asher/5/CompCr229// } \\
\text { As46/Pro/3/Srs/4/Bda }\end{array}$ & 10.30 & 4.42 & 42.92 & 3.33 & 2.50 & 46 & 50.80 \\
\hline 82 & $\begin{array}{l}\text { 80-5145/N-Acc4000-301-80//RWA-M54/6/Rhn-03/Asse/5/ } \\
\text { U.Sask.1766/Api//Cel/3/Weeah/4/Lignee527/NK1272 }\end{array}$ & 07.35 & 02.31 & 31.40 & 2.33 & 1.50 & 32 & 47.94 \\
\hline 83 & Rhn-03/3/Sutter//Sutter*2/Numar & 08.71 & 4.93 & 56.58 & 3.33 & 3.17 & 49 & 52.71 \\
\hline 84 & Rhn-03/4/Rhn-08/3/DeirAlla106//DL71/Strain205 & 09.15 & 4.73 & 51.70 & 3.83 & 3.00 & 46 & 46.17 \\
\hline 85 & $\begin{array}{l}\text { Centinela/2*Calicuchima/5/Alanda-02/4/Arizona5908/ } \\
\text { Aths//Asse/3/F208-74 }\end{array}$ & 09.60 & 4.72 & 49.22 & 3.33 & 2.83 & 48 & 46.52 \\
\hline 86 & Hamra//Lignee527/Rhn/3/Harra & 07.41 & 03.03 & 40.87 & 3.17 & 2.83 & 43 & 41.94 \\
\hline 87 & Tunisia/3/Lignee527/Chn-01//Lignee527/NK1272 & 06.07 & 2.47 & 40.66 & 2.67 & 2.17 & 36 & 39.80 \\
\hline 88 & Alanda/Hamra//M192 & 06.08 & 2.86 & 47.05 & 2.33 & 2.17 & 37 & 42.87 \\
\hline 89 & Carina/WI2291//Tilga & 09.11 & 04.21 & 46.20 & 5.00 & 4.00 & 24 & 49.73 \\
\hline 90 & Harmal & 06.83 & 02.69 & 39.40 & 3.67 & 2.83 & 29 & 41.13 \\
\hline 91 & Carina/WI2291//WI3180 & 08.79 & 03.53 & 40.15 & 3.83 & 3.50 & 27 & 47.64 \\
\hline 92 & Arda/Quinn/5/Roho/4/Zanbaka/3/ER/Apm//Lignee131 & 06.12 & 02.64 & 43.09 & 3.33 & 2.17 & 22 & 63.06 \\
\hline 93 & Rhn-03//Lignee527/NK1272/3/Rum & 06.29 & 02.55 & 40.49 & 2.00 & 2.00 & 33 & 57.03 \\
\hline 94 & Roho//Alger/Ceres362-1-1/3/Kantara/4/Bowman & 08.37 & 03.69 & 44.13 & 4.00 & 3.00 & 25 & 40.68 \\
\hline 95 & Zabad/5/Sfa-02/3/RM1508/Por//WI2269/4/Roho/Arabi Abiad & 07.65 & 03.39 & 44.34 & 3.33 & 3.17 & 24 & 49.86 \\
\hline 96 & Clipper//WI2291*2/WI2269 & 06.74 & 2.74 & 40.61 & 3.33 & 2.67 & 22 & 47.16 \\
\hline 97 & Matnan-01 & 10.14 & 4.69 & 46.28 & 2.83 & 2.67 & 53 & 56.63 \\
\hline 98 & National_check & 06.92 & 2.90 & 41.90 & 2.50 & 2.33 & 29 & 53.00 \\
\hline
\end{tabular}


Table 6b. Mean values of grain yield components of examined genotypes of barley in Al-Huson Field Campus

\begin{tabular}{|c|c|c|c|c|c|}
\hline Entry No. & Name & $\mathrm{PH}$ & HD & MD & GFP \\
\hline 1 & Harmal & 56.00 & 109.00 & 137.83 & 28.83 \\
\hline 2 & Tipper/ICB-102854//Alpha/Durra & 47.00 & 131.67 & 158.67 & 27.00 \\
\hline 3 & MRYT169/Mamluk//YEA389-3/YEA475-4 & 45.50 & 136.83 & 160.83 & 24.00 \\
\hline 4 & Lignee131/ArabiAbiad//Mal1-4-3094-2 & 44.00 & 135.67 & 163.00 & 27.33 \\
\hline 5 & WI2291/Roho//WI2269/3/Arta & 51.00 & 113.00 & 142.33 & 29.33 \\
\hline 6 & WI2291/Roho//WI2269/3/Arta & 52.67 & 117.00 & 142.33 & 25.33 \\
\hline 7 & WI2291/Roho//WI2269/3/Arta & 53.00 & 111.17 & 127.67 & 16.50 \\
\hline 8 & WI2291/Roho//WI2269/3/Arta & 54.33 & 114.50 & 136.50 & 22.00 \\
\hline 9 & WI2291/Roho//WI2269/3/Arta & 45.00 & 114.00 & 134.33 & 20.33 \\
\hline 10 & Matnan-01 & 58.17 & 125.33 & 142.67 & 17.33 \\
\hline 11 & WI2291/Roho//WI2269/3/Arta & 44.33 & 114.67 & 135.48 & 20.82 \\
\hline 12 & WI2291/Roho//WI2269/3/Arta & 46.00 & 114.00 & 135.50 & 21.50 \\
\hline 13 & WI2291/Roho//WI2269/3/Arta & 56.50 & 114.33 & 134.50 & 20.17 \\
\hline 14 & WI2291/Roho//WI2269/3/Arta & 45.67 & 113.67 & 134.67 & 21.00 \\
\hline 15 & WI2291/Roho//WI2269/3/Arta & 44.00 & 113.83 & 135.33 & 21.50 \\
\hline 16 & WI2291/Roho//WI2269/3/Arta & 43.50 & 120.00 & 134.83 & 14.83 \\
\hline 17 & SLB39-39/H.spont.41-5 & 56.17 & 115.17 & 136.67 & 21.50 \\
\hline 18 & SLB39-39/H.spont.41-5 & 56.33 & 113.33 & 134.50 & 21.17 \\
\hline 19 & Arar/H.spont.19-15//Arta & 52.67 & 113.83 & 133.50 & 19.67 \\
\hline 20 & National_check & 57.17 & 118.00 & 135.00 & 17.00 \\
\hline 21 & Arar/H.spont.19-15//Arta & 48.83 & 114.00 & 135.00 & 21.00 \\
\hline 22 & Arar/H.spont.19-15//Arta & 53.67 & 112.05 & 129.67 & 17.62 \\
\hline 23 & Arar/H.spont.19-15//Arta & 53.00 & 113.67 & 128.50 & 14.83 \\
\hline 24 & Arar/H.spont.19-15//Arta & 54.00 & 113.55 & 131.17 & 17.62 \\
\hline 25 & Moroc9-75/Harmal & 52.33 & 113.42 & 133.83 & 20.42 \\
\hline 26 & Moroc9-75/Harmal & 69.50 & 114.17 & 137.83 & 23.67 \\
\hline 27 & Moroc9-75/Harmal & 61.50 & 110.58 & 137.50 & 26.92 \\
\hline 28 & H.spont.21-3/Arar84//WI2269/3/Sara & 58.50 & 131.33 & 148.83 & 17.50 \\
\hline 29 & $\begin{array}{l}\text { ArabiAbiad/WI2291//Tadmor/4/H.spont.93-4/3/Roho//Alger } \\
\text { /Ceres362-1-1 }\end{array}$ & 69.17 & 116.83 & 144.27 & 27.43 \\
\hline 30 & Harmal & 72.67 & 113.33 & 142.33 & 29.00 \\
\hline 31 & WI2291/Tipper & 66.33 & 121.50 & 141.50 & 20.00 \\
\hline 32 & Akrash//WI2291/WI2269/3/WI2291/WI2269//WI2291/Bgs & 67.50 & 114.00 & 142.67 & 28.67 \\
\hline 33 & Akrash//WI2291/WI2269/3/WI2291/WI2269//WI2291/Bgs & 69.67 & 115.00 & 141.83 & 26.83 \\
\hline 34 & Akrash//WI2291/WI2269/3/WI2291/WI2269//WI2291/Bgs & 75.83 & 114.83 & 140.50 & 25.67 \\
\hline 35 & Akrash//WI2291/WI2269/3/WI2291/WI2269//WI2291/Bgs & 73.17 & 114.17 & 140.83 & 26.67 \\
\hline 36 & Akrash//WI2291/WI2269/3/WI2291/WI2269//WI2291/Bgs & 67.50 & 113.83 & 141.67 & 27.83 \\
\hline 37 & Akrash//WI2291/WI2269/3/WI2291/WI2269//WI2291/Bgs & 62.50 & 112.83 & 139.33 & 26.50 \\
\hline 38 & Akrash//WI2291/WI2269/3/WI2291/WI2269//WI2291/Bgs & 67.67 & 113.00 & 137.33 & 24.33 \\
\hline 39 & Mo.B1337/WI2291//Sls/Akrash-02 & 66.83 & 114.00 & 139.67 & 25.67 \\
\hline 40 & Matnan-01 & 56.17 & 118.00 & 144.83 & 26.83 \\
\hline 41 & Akrash//WI2291/WI2269/3/Arar/19-3//WI2291 & 62.50 & 114.72 & 140.67 & 25.95 \\
\hline 42 & ArabiAbiad/Arar/3/Arar/19-3//WI2291 & 77.00 & 119.00 & 144.50 & 25.50 \\
\hline 43 & ArabiAbiad/Arar/3/Arar/19-3//WI2291 & 71.17 & 116.83 & 145.00 & 28.17 \\
\hline 44 & Akrash//WI2291/WI2269/3/Sls/Akrash-02 & 61.83 & 116.17 & 148.00 & 31.83 \\
\hline 45 & H.spont.41-1/Tadmor/4/Gloria'S'/Copal'S'//Abn/3/Shyri & 55.50 & 124.83 & 150.67 & 25.83 \\
\hline 46 & $\begin{array}{l}\text { WI2269/Lignee131/3/SB73358-B-104-16-1-3//ER/Apm/5/ER/Apm } \\
\text { //Lignee131/4/ER/Apm/3/Arr/Esp//Alger/Ceres362-1-1 }\end{array}$ & 40.50 & 126.17 & 151.50 & 25.33 \\
\hline 47 & $\begin{array}{l}\text { WI2269/Lignee131/3/SB73358-B-104-16-1-3//ER/Apm/5/ER/Apm } \\
\text { //Lignee131/4/ER/Apm/3/Arr/Esp//Alger/Ceres362-1-1 }\end{array}$ & 54.33 & 128.58 & 146.33 & 17.75 \\
\hline 48 & $\begin{array}{l}\text { Mo.B1337/WI2291//Bonita/Weeah/5/ER/Apm//Lignee131/4/ } \\
\text { ER/Apm/3/Arr/Esp//Alger/Ceres362-1-1 }\end{array}$ & 58.83 & 115.00 & 144.67 & 29.67 \\
\hline
\end{tabular}




\begin{tabular}{|c|c|c|c|c|c|}
\hline 49 & SLB39-05/4/7028/2759/3/69-82//Ds/Apro & 67.50 & 115.67 & 139.67 & 24.00 \\
\hline 50 & National_check & 64.33 & 116.83 & 145.00 & 28.17 \\
\hline 51 & Viringa'S'//Hml-02/ArabiAbiad*2 & 75.83 & 114.33 & 139.83 & 25.50 \\
\hline 52 & Moroc9-75//WI2291/CI01387/3/H.spont.41-1/Tadmor & 82.33 & 114.00 & 140.00 & 26.00 \\
\hline 53 & ArabiAbiad/Arar//H.spont.41-5/Tadmor & 84.17 & 114.00 & 139.83 & 25.83 \\
\hline 54 & ArabiAbiad/Arar//H.spont.41-5/Tadmor & 85.83 & 113.33 & 140.00 & 26.67 \\
\hline 55 & Arta/Zabad & 65.33 & 113.33 & 142.17 & 28.83 \\
\hline 56 & Arta/Zabad & 66.83 & 114.00 & 143.67 & 29.67 \\
\hline 57 & $\begin{array}{l}\text { SLB45-58/Arta/6/WI2291/Bgs/5/Cq/Cm//Apm } \\
\text { /3/12410/4/Gizeh134-2L }\end{array}$ & 72.00 & 114.17 & 149.00 & 34.83 \\
\hline 58 & $\begin{array}{l}\text { Cerise/Lignee1479//Moroc9-75/PmB/3/JLB37-74/ } \\
\text { H.spont.41-5// JLB37-74/H.spont.41-5 }\end{array}$ & 73.50 & 109.83 & 142.50 & 32.67 \\
\hline 59 & Rum//Alanda/Hamra & 66.17 & 113.67 & 150.67 & 37.00 \\
\hline 60 & Harmal & 68.17 & 111.33 & 142.50 & 31.17 \\
\hline 61 & Rum//Alanda/Hamra & 59.17 & 113.00 & 151.83 & 38.83 \\
\hline 62 & Rum//Alanda/Hamra & 67.17 & 113.67 & 146.17 & 32.50 \\
\hline 63 & Rum//Alanda/Hamra & 73.33 & 113.50 & 150.17 & 36.67 \\
\hline 64 & Rum//Alanda/Hamra & 74.00 & 115.00 & 149.50 & 34.50 \\
\hline 65 & Rum//Alanda/Hamra & 73.17 & 114.33 & 148.67 & 34.33 \\
\hline 66 & Rum//Alanda/Hamra & 71.50 & 115.33 & 145.33 & 30.00 \\
\hline 67 & Rum/Manal & 74.83 & 114.67 & 148.17 & 33.50 \\
\hline 68 & Rum/Manal & 70.33 & 113.83 & 148.33 & 34.50 \\
\hline 69 & Beecher & 74.67 & 115.83 & 145.17 & 29.33 \\
\hline 70 & Matnan-01 & 71.67 & 116.50 & 148.17 & 31.67 \\
\hline 71 & Beecher & 75.67 & 115.67 & 144.33 & 28.67 \\
\hline 72 & Beecher & 78.00 & 113.83 & 150.00 & 36.17 \\
\hline 73 & Aths/Lignee686/4/Avt/Attiki//Aths/3/Giza121/Pue & 79.67 & 114.83 & 142.67 & 27.83 \\
\hline 74 & Mari/Aths*2//Avt/Attiki/3/Aths/Lignee686/4/Manal & 79.50 & 116.17 & 147.17 & 31.00 \\
\hline 75 & Mari/Aths*2//Avt/Attiki/3/Aths/Lignee686/4/Arar//Hr/Nopal & 69.33 & 116.83 & 141.50 & 24.67 \\
\hline 76 & Acc\#116132-Coll\#89023-11/Malouh & 72.00 & 113.33 & 142.50 & 29.17 \\
\hline 77 & Rhn-03/3/Api/CM67//Aths*3/4/Alanda-01 & 69.33 & 113.83 & 140.00 & 26.17 \\
\hline 78 & Lignee527/NK1272//Alanda/3/Arbayan-01//M6/Robur-35-6-3 & 63.83 & 116.50 & 144.50 & 28.00 \\
\hline 79 & Rhn-03//Arar/Lignee527 & 76.33 & 114.67 & 144.33 & 29.67 \\
\hline 80 & National_check & 60.50 & 115.00 & 143.83 & 28.83 \\
\hline 81 & $\begin{array}{l}\text { Kharda1/3/Lignee527/Chn-01//Asher/5/CompCr229//As46/Pro } \\
\text { /3/Srs/4/Bda }\end{array}$ & 75.50 & 116.00 & 143.67 & 27.67 \\
\hline 82 & $\begin{array}{l}\text { 80-5145/N-Acc4000-301-80//RWA-M54/6/Rhn-03/Asse/5/ } \\
\text { U.Sask.1766/Api//Cel/3/Weeah/4/Lignee527/NK1272 }\end{array}$ & 59.67 & 116.83 & 145.00 & 28.17 \\
\hline 83 & Rhn-03/3/Sutter//Sutter*2/Numar & 69.17 & 116.33 & 150.83 & 34.50 \\
\hline 84 & Rhn-03/4/Rhn-08/3/DeirAlla106//DL71/Strain205 & 72.67 & 117.83 & 151.50 & 33.67 \\
\hline 85 & $\begin{array}{c}\text { Centinela/2*Calicuchima/5/Alanda-02/4/Arizona5908/Aths } \\
\qquad / / \text { Asse/3/F208-74 }\end{array}$ & 67.00 & 120.83 & 146.83 & 26.00 \\
\hline 86 & Hamra//Lignee527/Rhn/3/Harra & 66.17 & 117.33 & 151.00 & 33.67 \\
\hline 87 & Tunisia/3/Lignee527/Chn-01//Lignee527/NK1272 & 68.17 & 115.67 & 146.50 & 30.83 \\
\hline 88 & Alanda/Hamra//M192 & 64.83 & 115.50 & 141.67 & 26.17 \\
\hline 89 & Carina/WI2291//Tilga & 65.00 & 117.17 & 146.83 & 29.67 \\
\hline 90 & Harmal & 68.50 & 115.33 & 140.50 & 25.17 \\
\hline 91 & Carina/WI2291//WI3180 & 70.17 & 117.67 & 150.00 & 32.33 \\
\hline 92 & Arda/Quinn/5/Roho/4/Zanbaka/3/ER/Apm//Lignee131 & 73.00 & 116.33 & 145.00 & 28.67 \\
\hline 93 & Rhn-03//Lignee527/NK1272/3/Rum & 68.67 & 114.33 & 149.00 & 34.67 \\
\hline 94 & Roho//Alger/Ceres362-1-1/3/Kantara/4/Bowman & 65.83 & 114.83 & 141.67 & 26.83 \\
\hline 95 & Zabad/5/Sfa-02/3/RM1508/Por//WI2269/4/Roho/Arabi Abiad & 68.33 & 112.67 & 142.17 & 29.50 \\
\hline 96 & Clipper//WI2291*2/WI2269 & 68.33 & 115.67 & 141.67 & 26.00 \\
\hline 97 & Matnan-01 & 61.33 & 116.33 & 157.00 & 40.67 \\
\hline 98 & National_check & 67.00 & 117.17 & 143.83 & 26.67 \\
\hline
\end{tabular}


Table 7a. Genetic parameters for some characteristics in barley genotypes grown during two seasons 2005/2006 and $2007 / 2008$ under field conditions

\begin{tabular}{|l|c|c|c|c|c|c|c|c|}
\hline \multirow{2}{*}{$\begin{array}{l}\text { Source } \\
\text { variance }\end{array}$} & \multicolumn{9}{|c|}{ Mean square } \\
\cline { 2 - 9 } & BY & GY & HI & TN & FTN & KN & TKW & PH \\
\hline$\sigma_{\mathrm{g}}^{2}$ & 2.50 & 0.63 & 28.28 & 0.17 & 0.16 & 108.93 & 52.10 & 104.08 \\
\hline$\sigma_{\text {ph }}^{2}$ & 2.63 & 0.63 & 34.93 & 0.25 & 0.22 & 110.25 & 55.04 & 105.99 \\
\hline Heritability \% & 95.24 & 99.73 & 80.97 & 68.00 & 74.62 & 98.80 & 94.65 & 98.20 \\
\hline GCV (\%) & 22.86 & 26.04 & 12.02 & 13.26 & 16.28 & 35.24 & 14.93 & 15.91 \\
\hline PCV (\%) & 23.42 & 26.07 & 13.36 & 16.08 & 18.85 & 35.45 & 15.35 & 16.06 \\
\hline GA & 3.18 & 1.63 & 9.86 & 0.70 & 0.72 & 21.37 & 14.47 & 20.83 \\
\hline GAM & 45.95 & 53.57 & 22.29 & 22.52 & 28.97 & 72.15 & 29.92 & 32.48 \\
\hline & & & & & & & & \\
\hline
\end{tabular}

* Significant at the 0.05 probability level.

Table $7 \mathrm{~b}$. Genetic parameters for some characteristics in barley genotypes grown during two seasons $2005 / 2006$ and 2007 / 2008 under field conditions

\begin{tabular}{|l|c|c|c|}
\hline \multirow{2}{*}{ Source of variance } & \multicolumn{3}{|c|}{ Mean square } \\
\cline { 2 - 4 } & HD & MD & GFP \\
\hline$\sigma_{\mathrm{G}}^{2}$ & 22.40 & 39.97 & 27.30 \\
\hline$\sigma_{\mathrm{P}}^{2}$ & 23.01 & 42.25 & 29.56 \\
\hline Heritability \% & 97.33 & 94.60 & 92.38 \\
\hline GCV (\%) & 4.08 & 4.42 & 19.40 \\
\hline PCV (\%) & 4.13 & 4.54 & 20.19 \\
\hline GA & 9.62 & 12.67 & 10.35 \\
\hline GAM & 8.28 & 8.85 & 38.42 \\
\hline
\end{tabular}

* Significant at the 0.05 probability level.

Table 8. Genotypic (Bold) and phenotypic correlations among different quantitative characters in barley

\begin{tabular}{|l|l|l|l|l|l|l|l|l|l|l|l|}
\hline & $\mathrm{BY}$ & $\mathrm{GY}$ & $\mathrm{HI}$ & $\mathrm{TN}$ & $\mathrm{FTN}$ & $\mathrm{KN}$ & $\mathrm{TKW}$ & $\mathrm{PH}$ & $\mathrm{HD}$ & $\mathrm{MD}$ & $\mathrm{GFP}$ \\
\hline $\mathrm{BY}$ & 1 & $\mathbf{0 . 9 2} * *$ & $\mathbf{- 0 . 2 2} * *$ & $\mathbf{0 . 3 9} * *$ & $\mathbf{0 . 6 0} * *$ & $\mathbf{0 . 7 1} * *$ & $\mathbf{0 . 1 8} * *$ & $\mathbf{0 . 7 1} * *$ & $\mathbf{- 0 . 1 6} * *$ & $\mathbf{0 . 4 2} * *$ & $\mathbf{0 . 6 6} * *$ \\
\hline $\mathrm{GY}$ & $0.78 * *$ & 1 & $\mathbf{0 . 1 7} * *$ & $\mathbf{0 . 4 8}$ & $\mathbf{0 . 6 8} * *$ & $\mathbf{0 . 7 7} * *$ & $\mathbf{0 . 2 7} * *$ & $\mathbf{0 . 5 5} * *$ & $\mathbf{- 0 . 3 0} * *$ & $\mathbf{0 . 2 6} * *$ & $\mathbf{0 . 6 0} * *$ \\
\hline $\mathrm{HI}$ & $-0.11 * *$ & $0.49 * *$ & 1 & $\mathbf{0 . 0 5} * *$ & $\mathbf{0 . 1 4} * *$ & $\mathbf{0 . 1 4} * *$ & $\mathbf{0 . 2 9} * *$ & $\mathbf{- 0 . 3 4} * *$ & $\mathbf{- 0 . 5 1} * *$ & $\mathbf{- 0 . 5 3} * *$ & $\mathbf{- 0 . 1 8} * *$ \\
\hline TN & $0.34 * *$ & $0.31 * *$ & 0.03 & 1 & $\mathbf{0 . 9 2} * *$ & $\mathbf{- 0 . 0 8} * *$ & $\mathbf{0 . 1 6} * *$ & $\mathbf{0 . 1 9} * *$ & $\mathbf{- 0 . 0 9} * *$ & $\mathbf{- 0 . 0 9} * *$ & $\mathbf{- 0 . 0 2} * *$ \\
\hline FTN & $0.31 * *$ & $0.33 * *$ & $0.08 *$ & $0.56 * *$ & 1 & $\mathbf{0 . 1 2} * *$ & $\mathbf{0 . 1 0} * *$ & $\mathbf{0 . 2 9} * *$ & $\mathbf{- 0 . 2 0} * *$ & $\mathbf{0 . 0 5} * *$ & $\mathbf{0 . 2 4} * *$ \\
\hline KN & $0.53 * *$ & $0.52 * *$ & 0.08 & -0.03 & 0.07 & 1 & $\mathbf{- 0 . 0 6} * *$ & $\mathbf{0 . 4 2} * *$ & $\mathbf{- 0 . 1 3} * *$ & $\mathbf{0 . 4 0} * *$ & $\mathbf{0 . 6 0} * *$ \\
\hline TKW & $0.15 * *$ & $0.33 * *$ & $0.15 * *$ & 0.04 & 0.03 & -0.04 & 1 & $\mathbf{0 . 2 7} * *$ & $\mathbf{- 0 . 4 1} * *$ & $\mathbf{- . 1 6} * *$ & $\mathbf{0 . 1 7} * *$ \\
\hline PH & $0.50 * *$ & $0.35 * *$ & $-0.11 * *$ & $0.09 * *$ & $0.18 * *$ & $0.38 * *$ & $0.22 * *$ & 1 & $\mathbf{- 0 . 3 4} * *$ & $\mathbf{0 . 2 0} * *$ & $\mathbf{0 . 5 6} * *$ \\
\hline HD & $-0.12 * *$ & $0.15 * *$ & $-0.18 * *$ & -0.03 & $-0.09 * *$ & $-0.10 * *$ & $-0.33 * *$ & $-0.28 * *$ & 1 & $\mathbf{0 . 5 9} * *$ & $\mathbf{- 0 . 1 9 * *}$ \\
\hline MD & $0.28 * *$ & $0.15 * *$ & $-0.20 * *$ & -0.02 & 0.006 & $0.33 * *$ & $-0.13 * *$ & $0.17 * *$ & $0.51 * *$ & 1 & $\mathbf{0 . 6 8} * *$ \\
\hline GFP & $0.41 * *$ & $0.31 * *$ & $-0.09 * *$ & -0.01 & 0.08 & $0.46 * *$ & $0.12 * *$ & $0.42 * *$ & -0.21 & $0.73 * *$ & 1 \\
\hline$* * *$ Significant at 0.05 and 0.01 level, respectively & & & & & & \\
\hline
\end{tabular}


Table 9. Multiple correlation analysis of grain yield per plant on the basis of all yield components (Col. 1) and on the basis of fertile tillers number and number of kernels per main spike (Col. 2)

\begin{tabular}{|l|l|l|}
\hline & Col. 1 & Col. 2 \\
\hline Multiple correlation & & \\
\hline Coefficient of determination $\left(\mathrm{R}^{2}\right)$ & 0.9635 & 0.3638 \\
\hline Adjusted R-square & 0.9629 & 0.3616 \\
\hline Standard error & 0.2214 & 0.8773 \\
\hline
\end{tabular}

** Significant at 0.01 Level

Table 10a. Partial regression analysis of grain yield with its components in barley genotypes

\begin{tabular}{|l|l|l|l|}
\hline Yield component & Partial regression coefficient (B) & S.E (B) & “ $t$ " \\
\hline Fertile tiller number & $0.0584^{* *}$ & 0.01534 & 3.81 \\
\hline Number of kernel per main spike & $0.00244^{*}$ & 0.00109 & 2.24 \\
\hline Thousand kernel weight & 0.00004 & 0.00115 & 0.41 \\
\hline Plant height & -0.0008 & 0.0010 & -0.81 \\
\hline Heading date & $0.0038^{*}$ & 0.0016 & 2.32 \\
\hline Maturity date & 0.0030 & 0.0023 & 1.27 \\
\hline
\end{tabular}

*, ** Significant at 0.05 and 0.01 level, respectively.

Table 10b. Partial regression analysis of grain yield with fertile tillers number and number of kernels per main spike in barley genotypes

\begin{tabular}{|l|c|c|c|}
\hline Yield component & Partial regression coefficient (B) & S.E (B) & " t” \\
\hline Fertile tiller number & $0.470 * *$ & 0.0514 & 9.15 \\
\hline Number of kernel per main spike & $0.050 * *$ & 0.003 & 15.13 \\
\hline
\end{tabular}

*, ** Significant at 0.05 and 0.01 level, respectively. 